University of Nebraska - Lincoln

DigitalCommons@University of Nebraska - Lincoln

\title{
Timing and warmth of the Last Interglacial period: new U-series evidence from Hawaii and Bermuda and a new fossil compilation for North America
}

\author{
Daniel R. Muhs \\ US Geological Survey, dmuhs@usgs.gov \\ Kathleen R. Simmons \\ US Geological Survey, ksimmons@usgs.gov \\ Bree Steinke \\ US Geological Survey
}

Follow this and additional works at: https://digitalcommons.unl.edu/usgsstaffpub

Part of the Earth Sciences Commons

Muhs, Daniel R.; Simmons, Kathleen R.; and Steinke, Bree, "Timing and warmth of the Last Interglacial period: new U-series evidence from Hawaii and Bermuda and a new fossil compilation for North America" (2002). USGS Staff -- Published Research. 179.

https://digitalcommons.unl.edu/usgsstaffpub/179

This Article is brought to you for free and open access by the US Geological Survey at DigitalCommons@University of Nebraska - Lincoln. It has been accepted for inclusion in USGS Staff -- Published Research by an authorized administrator of DigitalCommons@University of Nebraska - Lincoln. 


\title{
Timing and warmth of the Last Interglacial period: new U-series evidence from Hawaii and Bermuda and a new fossil compilation for North America
}

\author{
Daniel R. Muhs, Kathleen R. Simmons, Bree Steinke ${ }^{1}$ \\ US Geological Survey, MS 980, Box 25046, Federal Center, Denver, CO 80225, USA \\ Received 29 January 2001; accepted 12 September 2001
}

\begin{abstract}
The timing and duration of the Last Interglacial period have been controversial, with some studies suggesting a relatively short duration that is orbitally forced and others suggesting a long duration that is at most only partly related to orbital forcing. New, high-precison thermal ionization mass spectrometric (TIMS) U-series ages of Last Interglacial corals from Hawaii and Bermuda test these competing hypotheses. Waimanalo Formation corals from slowly uplifting Oahu, Hawaii range in age from $\sim 134$ to $\sim 113 \mathrm{ka}$, with most ages between $\sim 125$ and $\sim 115 \mathrm{ka}$. Combined with published U-series ages from nearby Lanai, the data suggest a long Last Interglacial period that may have occurred from $\sim 136$ to at least $115 \mathrm{ka}$. The results indicate that orbital forcing may not have been the only control on ice sheet growth and decay, because sea level would have been high at times of relatively low Northern Hemisphere summer insolation. On tectonically stable Bermuda, deposits from the $\sim 200$ ka (penultimate interglacial period), $\sim 120 \mathrm{ka}$ (peak Last Interglacial period) and $\sim 80 \mathrm{ka}$ (late Last Interglacial period) high sea stands have been newly dated. Fossil corals on Bermuda are derived from patch reefs that likely were "catch-up" responses to sea level rise. It is expected that U-series ages of Last-Interglacial corals on Bermuda should overlap with, but not be as old as the range of corals on Oahu. Last-Interglacial corals on Bermuda give a range of $\sim 125-113 \mathrm{ka}$, which supports this hypothesis.

A large number of emergent marine deposits on Hawaii, Bermuda and along coastal North America have now been dated to the Last Interglacial period. Both Oahu and Bermuda have marine invertebrate faunas with a number of extralimital southern species of mollusks, suggesting warmer-than-present waters during the Last Interglacial period. Warmer waters are also suggested for LastInterglacial localities around most of North America, from Florida to Canada and Greenland and Baja California to Alaska. These observations are consistent with similar warm-water faunas of Last-Interglacial age reported from Japan, the Mediterranean basin and Western Australia. It is likely that significant changes in ocean currents took place during the Last Interglacial period, with a movement of relatively warm waters to higher latitudes than is the case today. (C) 2002 Elsevier Science Ltd. All rights reserved.
\end{abstract}

\section{Introduction}

The precise timing, duration and paleoclimatic conditions of the peak of the Last Interglacial period have been actively debated. It is an important time period to study because understanding its causes, duration and paleoclimatic conditions may provide clues to climates of the future (Broecker, 1998). Interpretation of the oxygen isotope record of foraminifera in deep-sea cores

Corresponding author. Tel.: + 1-303-236-7919; fax: +1-303-2365349 .

E-mail address: dmuhs@usgs.gov (D.R. Muhs).

${ }^{1}$ Present address: 19026 E. Bethany Place, Aurora, CO 80013, USA. suggests that the Last Interglacial period (known as substage 5e) began around $127 \mathrm{ka}$, was relatively short (on the order of a few thousand years) and was orbitally forced (CLIMAP Project Members, 1984; Martinson et al., 1987). However, records from deep-sea cores (McManus et al., 1994), pollen from Grand Pile, France (Kukla et al., 1997), vein calcite from Devils Hole, Nevada (Winograd et al., 1992, 1997), Antarctic ice cores (Lorius et al., 1985; Jouzel et al., 1993) and emergent reefs on Hawaii (Szabo et al., 1994) suggest that the Last Interglacial period could have been much longer, on the order of $20 \mathrm{ka}$. In addition, Henderson and Slowey (2000) directly dated marine sediments that have an interglacial oxygen isotope signature off the 
Bahamas using a U-Th isochron method. They proposed that the Last Interglacial could have begun as much as $8 \mathrm{ka}$ earlier than the $\sim 127 \mathrm{ka}$ starting date previously suggested (CLIMAP Project Members, 1984 and Martinson et al., 1987). If this earlier age estimate is correct, it challenges the hypothesis that the Last Interglacial period was orbitally forced.

Despite the challenges to the widely accepted deep-sea record of the Last Interglacial period, there are problems with many of the studies cited above. The Grand Pile pollen record is not dated directly and the chronology proposed by Kukla et al. (1997) is based on a correlation to the deep-sea record. Direct U-Th dating of sediments off the Bahamas by Henderson and Slowey (2000) is complicated by relatively high amounts of inherited ${ }^{230} \mathrm{Th}$ and therefore requires a model for correction of apparent ages. As pointed out by McCulloch and Esat (2000), many of the U-series ages of corals from Hawaii reported by Szabo et al. (1994) have relatively large analytical uncertainties. Antarctic ice cores contain neither direct records of global ice volume, nor are they dated directly. The Devils Hole, Nevada vein calcite record has a robust suite of U-series ages for chronological control, but the oxygen isotope record in this calcite does not measure global ice volume even indirectly. Indeed, Winograd et al. (1997) have pointed out that the oxygen isotope record at Devils Hole is a temperature record that may well precede that of the deep-sea oxygen isotope record.

Sea level records on different coastlines could very well differ in their estimates of the duration of the Last Interglacial, due both to tectonics and the rate of reef growth. Edwards et al. (1987) pointed out that the timing of reef growth during an interglacial period is a function not only of the rate of sea level rise, but also of the rate of uplift (Fig. 1). On a tectonically active, rapidly rising coastline, vertical reef accretion can take place when the rate of sea level rise slightly exceeds the rate of uplift. To this can be added the complicating effects of reef type, which consist of "keep-up," "catchup" or "give-up" types (Neumann and MacIntyre, 1985). This concept was applied by Neumann and MacIntyre (1985) to Atlantic and Caribbean reefs, but has also been useful in understanding reefs in the IndoPacific province (Cabioch et al., 1999). Sea level rise in a deglacial period can be rapid. Rates of $2-7 \mathrm{~mm} / \mathrm{yr}$ occurred during most of the last deglacial period on Barbados and meltwater "pulses" of up to $24 \mathrm{~m}$ occurred in less than 1000 radiocarbon years (Fairbanks, 1989). Certain types of corals may have matching growth rates and others may not. Fringing or barrier reefs dominated by Acropora palmata communities (such as those on uplifting Barbados or Haiti) can "keep up" with rising sea level and reef growth may continue after sea level has stabilized. Whereas most corals grow at rates of $1-10 \mathrm{~mm} / \mathrm{yr}$ (Grigg, 1997),



Fig. 1. Model of interglacial sea level rise and fall with hypothesized timing of different reef records. Modified from Bradley and Griggs (1976) and Edwards et al. (1987) using reef classification nomenclature of Neumann and MacIntyre (1985).

Acropora palmata has measured rates of $13-15 \mathrm{~mm} / \mathrm{yr}$ (Buddemeier and Smith, 1988). Other coral communities, such as patch reefs, are referred to as "catch-up" types, whose development may be delayed until sea level has stabilized. Patch reefs are the predominant types on Bermuda (Garrett et al., 1971). On Oahu, Hawaii, fringing reefs are present. During the mid-to-late Holocene, vertical accretion rates of Hawaiian reefs were about $3 \mathrm{~mm} / \mathrm{yr}$ (Easton and Olson, 1976). Given the model of Neumann and MacIntyre (1985), fossil reefs on Oahu may provide a fairly complete record of the Last Interglacial high sea stand. On Oahu, it can be hypothesized that reef development may keep pace with rising sea level during at least part of a deglacial period (thus potentially allowing a record of the early part of a sea-level rise). In addition, relatively slow uplift (Muhs and Szabo, 1994) may allow for maintenance of reef structures after sea level has stabilized.

It is important to note, however, that in both fringing reef and barrier reef environments, there is likely a lag between the time of initial sea level rise and vigorous, upward reef accretion. Lack of a suitable substrate, absence of larval replenishment centers, restricted circulation, poor water quality (highly turbid conditions), proximity to terrestrial influences and other factors can all result in a delay between the time of sea level rise and vertical reef accretion (Hopley, 1982, 1994). For example, in the Great Barrier Reef, Davies and Hopley (1983) report a hiatus of up to $2000 \mathrm{yr}$ between the time of Holocene sea level rise and the time of reef colonization. Many Holocene reefs thus date 
their initial growth to $7000-8000$ radiocarbon yr BP. In the Caribbean Sea and western Atlantic Ocean, growth of corals in the early Holocene was terminated by stress conditions induced by flooding of shelves as sea level rose; coral growth resumed when conditions improved around 7000 radiocarbon yr BP (MacIntyre, 1988). Thus, the oldest Holocene Acropora palmata (a "keepup" species) on fringing reefs off Panama and St. Croix date to around 5000-7000 radiocarbon yr BP. Studies of a Holocene reef on Oahu show that reef growth also began about 7000 radiocarbon yr ago, and was characterized by its most rapid vertical accretion from about 5800-3500 radiocarbon yr ago (Easton and Olson, 1976). The period of rapid vertical accretion was followed by a period of seaward accretion (since 3000 radiocarbon yr ago).

In this paper, we present new thermal ionization mass spectrometric (TIMS) U-series ages of pristine corals from marine deposits on Oahu, Hawaii and the tectonically stable island of Bermuda. We hypothesize that on a slowly rising, fringing-reef island setting such as Oahu, there should be a fairly complete record of a high sea stand such as the Last Interglacial period. We further hypothesize that on a tectonically stable island such as Bermuda, characterized mostly by patch reefs, past sea level records should overlap with, but not be as old as those of tectonically rising islands with fringing reef communities. Although there have already been extensive alpha-spectrometric U-series dating efforts on Oahu (Ku et al., 1974; Muhs and Szabo, 1994) and Bermuda (Harmon et al., 1978, 1983), testing of these hypotheses requires high-precision TIMS U-series dating. Szabo et al. (1994) reported a large suite of TIMS U-series ages of corals from Oahu, but two-sigma analytical uncertainties of these ages range from 1 to $6 \mathrm{ka}$. A rigorous testing of the hypotheses regarding the duration of the Last Interglacial period requires U-series ages with smaller analytical uncertainties. The new TIMS U-series ages reported here are from corals either not previously analyzed by Szabo et al. (1994) or analyzed only by alpha spectrometry by Muhs and Szabo (1994); all have improved analytical uncertainties.

We also compiled fossil faunal data (mostly mollusks) from marine deposits of Oahu and Bermuda, and compared these with their modern geographic ranges to assess the degree of zoogeographic shift during the Last Interglacial period. The paleoclimatic interpretations made from the Last-Interglacial faunal data of Oahu and Bermuda are also compared to those from marine deposits around North America. Examination of this compilation allows a test of the hypothesis that the Last Interglacial period was only about as warm as the present interglacial (CLIMAP Project Members, 1984; McCulloch and Esat, 2000) or at most slightly warmer (Montoya et al., 1998).

\section{Study areas}

\subsection{Oahu, Hawaii}

Oahu is part of the Hawaii-Emperor volcanic chain that extends across $6000 \mathrm{~km}$ of the Pacific Ocean. The best estimates of the age of the main volcanic rocks on Oahu are 2.6 and 3.7 Ma for the Koolau and Waianae Ranges, respectively (Clague and Dalrymple, 1987). Although the surficial geology of Oahu is dominated by Tertiary basalt, Pleistocene reef limestones fringe much of the island (Fig. 2). Some, although not all, of this limestone belongs to the Waimanalo Formation of Lum and Stearns (1970), which dates to the Last Interglacial period (Ku et al., 1974; Muhs and Szabo, 1994; Szabo et al., 1994). The Waimanalo Formation consists of corals in growth position, usually overlain by poorly sorted marine conglomerate with coral and basalt clasts. In some places, the reef facies is not present and limestones consist only of coral-basalt conglomerate resting on a marine bench or shore platform cut into Tertiary basalt.

The "Big Island" of Hawaii is situated near the stillactive volcanic hot spot that created the HawaiiEmperor island chain. Crustal subsidence of this island due to volcanic loading has been well documented (Szabo and Moore, 1986; Moore, 1987; Watts and ten Brink, 1989; Ludwig et al., 1991). This subsidence is hypothesized to have created a compensatory, upward lithospheric flexure on Oahu (Muhs and Szabo, 1994). Thus, Waimanalo Formation reefs, conglomerates and beach deposits at some localities on Oahu are somewhat higher (up to $13 \mathrm{~m}$ above sea level) than Last-Interglacial localities on tectonically quiescent islands and coastlines, such as Bermuda or Australia (Muhs and Szabo, 1994).

\subsection{Bermuda}

Bermuda is situated in the Atlantic Ocean, $\sim 1000 \mathrm{~km}$ to the east of North America (Fig. 3). The island has a core of pre-Quaternary volcanic rocks derived from the Mid-Atlantic Ridge, but its surficial deposits are Quaternary carbonates, mostly eolianite (Fig. 4). Isolated sublittoral marine and beach deposits and some emergent, fossil patch reefs are present also as marine facies, along with the volumetrically larger eolian facies (Vacher et al., 1989). Hermatypic corals are present around Bermuda because the island is bathed by the warm Gulf Stream current.

Detailed mapping and stratigraphic studies in the past 15 years have clarified the Quaternary stratigraphy of Bermuda (Vacher and Hearty, 1989; Vacher et al., 1989, 1995; Hearty et al., 1992; Hearty and Kindler, 1995; Vacher and Rowe, 1997). Most of the marine deposits are assigned to the Belmont Formation ( $200 \mathrm{ka})$ or the 


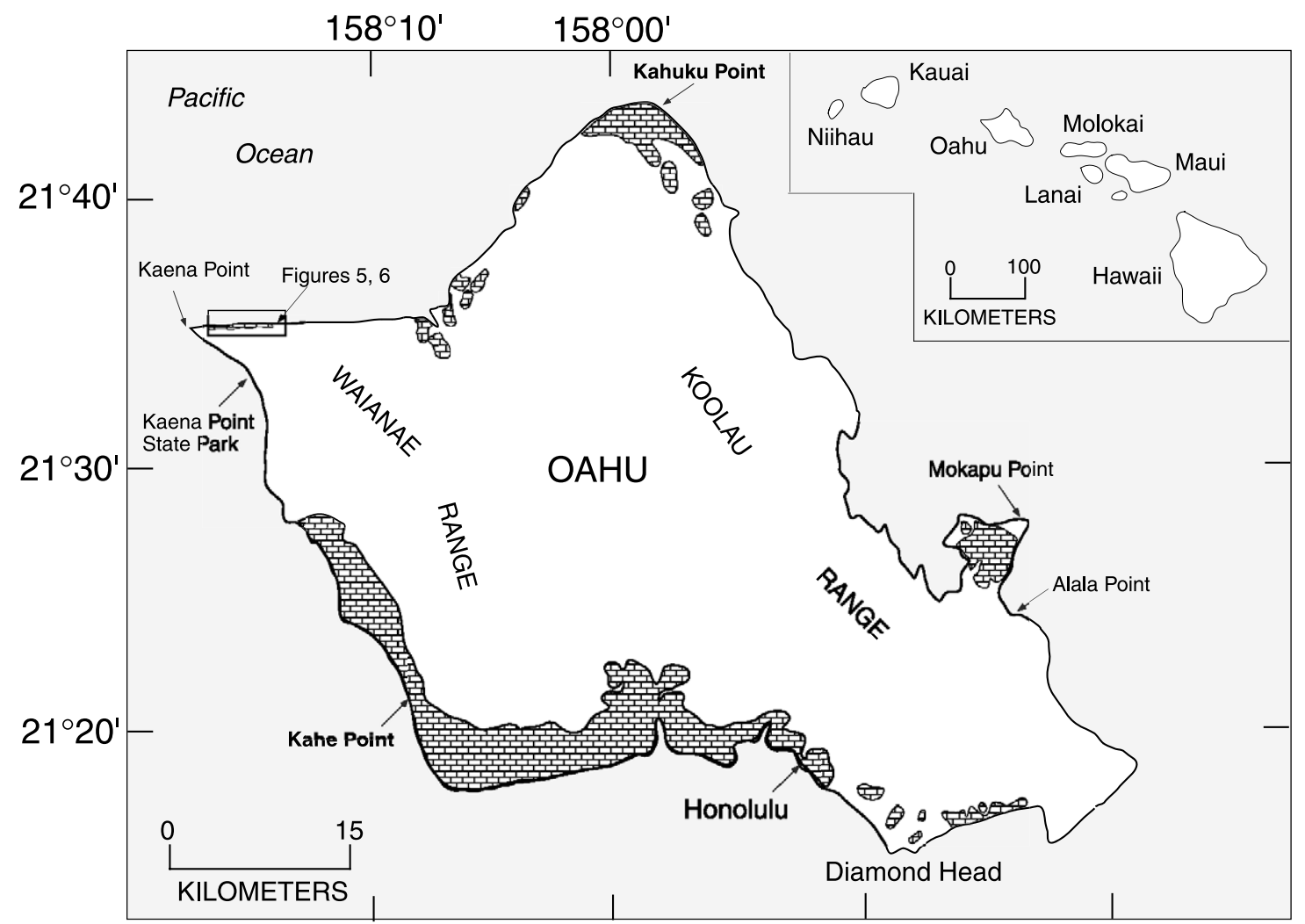

Fig. 2. Map of the island of Oahu, distribution of reef limestone (from Stearns, 1974, 1978, 1985) and fossil coral localities of the Waimanalo Formation referred to in the text. Place names in bold are confirmed $\sim 120 \mathrm{ka}$, mollusk-bearing localities of the Waimanalo Formation (from this study and Szabo et al., 1994) studied by Ostergaard (1928) and Kosuge (1969).

Devonshire marine member of the Rocky Bay Formation $(\sim 125 \mathrm{ka})$ (Vacher et al., 1989). Age estimates of these two formations are based on alpha-spectrometric U-series dating of corals (Harmon et al., 1978, 1983). Both formations have eolianite facies that overlie the marine facies. A younger unit, the Southampton Formation, can be differentiated from the Rocky Bay Formation on the basis of stratigraphic relations (Vacher et al., 1989, 1995) and amino acid racemization data from mollusks and whole-rock bioclastic sediment (Hearty et al., 1992). In addition, Harmon et al. (1983) reported a single alpha-spectrometric U-series age of $85 \pm 12 \mathrm{ka}$ ( 2 sigma) for a coral (Oculina sp.) collected from the Southampton marine facies near Fort St. Catherine. Ludwig et al. (1996) also reported four TIMS U-series ages of $\sim 80 \mathrm{ka}$ from Oculina corals from Fort St. Catherine.

\section{Materials and methods}

On Oahu, we visited most known localities of the Waimanalo Formation, described and measured coastal sections using hand level and tape, and collected corals for U-series dating. Some of the stratigraphic data are reported in Muhs and Szabo (1994) and other data are new. We also studied the stratigraphic relations of marine and eolian deposits at a number of localities on Bermuda and collected corals for U-series dating from the Devonshire marine member at Grape Bay and from the Southampton Formation at Fort St. Catherine. Additional corals from both the Devonshire marine member and the Belmont Formation at Grape Bay, collected by $\mathrm{H}$. Lowenstam in the 1950s, were also analyzed.

Analyzed corals were cleaned mechanically, washed in distilled water and $\mathrm{X}$-rayed for aragonite purity. Oahu samples HA-13C, HA-19A, HA-19B, and HA-20B were 96-97\% aragonite; all others were $99-100 \%$ aragonite. For Bermuda, sample GB-3 was 95\% aragonite and GB-10 was 97\% aragonite; all other samples were 99$100 \%$ aragonite. Sample preparation followed methods outlined by Ludwig et al. (1992) and is summarized briefly here. Cleaned corals were dissolved in $\mathrm{HNO}_{3}$, spiked with ${ }^{229} \mathrm{Th},{ }^{233} \mathrm{U}$, and ${ }^{236} \mathrm{U}$ and purified with ion exchange methods. Purified $\mathrm{U}$ and $\mathrm{Th}$ were loaded with colloidal graphite on separate Re filaments; isotopic abundances were determined by thermal ionization mass spectrometry. Ages were calculated using a half-life of $75,381 \mathrm{yr}$ for ${ }^{230} \mathrm{Th}$ and $244,600 \mathrm{yr}$ for ${ }^{234} \mathrm{U}$ (Tables 1 and 2). Cheng et al. (2000) re-determined the half-life of ${ }^{230} \mathrm{Th}$ to be $75,690 \mathrm{yr}$ and the half-life of ${ }^{234} \mathrm{U}$ to be 


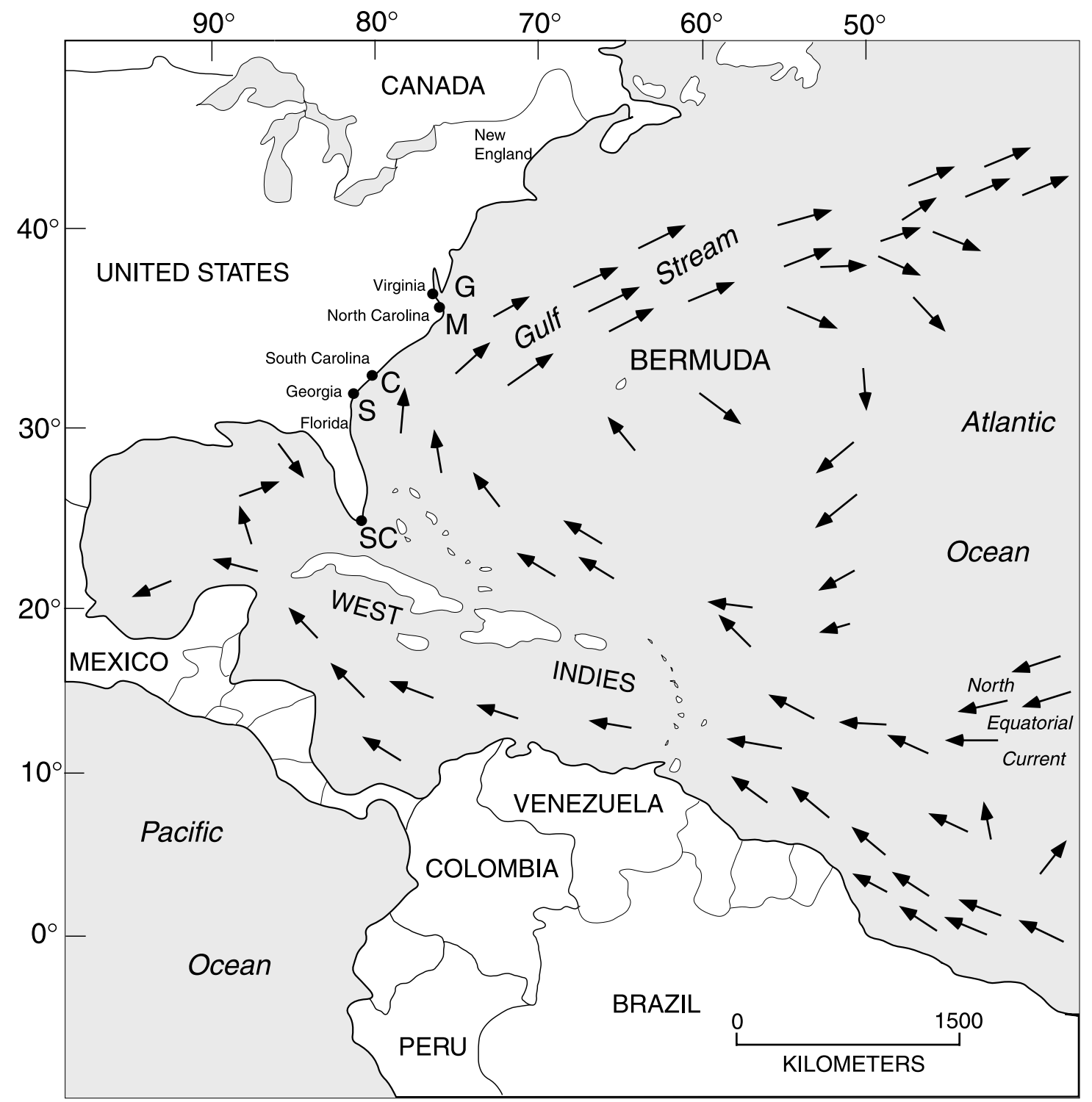

Fig. 3. Map of the western Atlantic Ocean adjacent to North and South America, location of Bermuda, major ocean currents, and 80 ka localities referred to in the text. SC, Sand Key, Florida; S, Savannah (Skidaway Island), Georgia; C, Charleston (Mt. Pleasant), South Carolina; M, Moyock, North Carolina; G, Gomez, Virginia.

$245,250 \mathrm{yr}$. Recalculation of our U-series data using these new half-lives results in ages that are in agreement, within analytical uncertainty, with ages calculated using the older half-lives (Table 3). Duplicate analyses of individual coral samples generally show excellent agreement, within limits of analytical uncertainty (Tables 1 and 2).

A consensus has developed among U-Th geochronologists that several conditions must be met in order for U-series ages of corals to be considered reliable. These include: (1) little or no evidence of recrystallization to calcite, (2) U concentrations similar to those present in living specimens of the same genus, (3) presence of little or no "inherited" ${ }^{230} \mathrm{Th}$, as indicated by low concentrations of ${ }^{232} \mathrm{Th}$ and high ${ }^{230} \mathrm{Th} /{ }^{232} \mathrm{Th}$ values, and (4) a calculated initial ${ }^{234} \mathrm{U} /{ }^{238} \mathrm{U}$ value in agreement, within analytical uncertainty, with that measured in modern sea water (activity ratio of about 1.148; see Chen et al., 1986). In most U-series studies of corals the usual problem encountered is a calculated initial ${ }^{234} \mathrm{U} /{ }^{238} \mathrm{U}$ value that is higher than that measured in modern sea water. Empirical observations from the Bahamas, New Guinea, Australia, and Barbados (Chen et al., 1991; Stein et al., 1993; Stirling et al., 1995, 1998; Edwards et al., 1997; Esat et al., 1999) and modeling studies (Gallup et al., 1994) have shown that higher-thanmodern calculated initial ${ }^{234} \mathrm{U} /{ }^{238} \mathrm{U}$ values bias corals to older apparent ages. Esat et al. (1999) used an upper limit of initial ${ }^{234} \mathrm{U} /{ }^{238} \mathrm{U}$ activity of 1.157 and a lower limit of 1.149 as a range for corals that were considered 


\section{$64^{\circ} 50^{\prime} \mathrm{W}$}

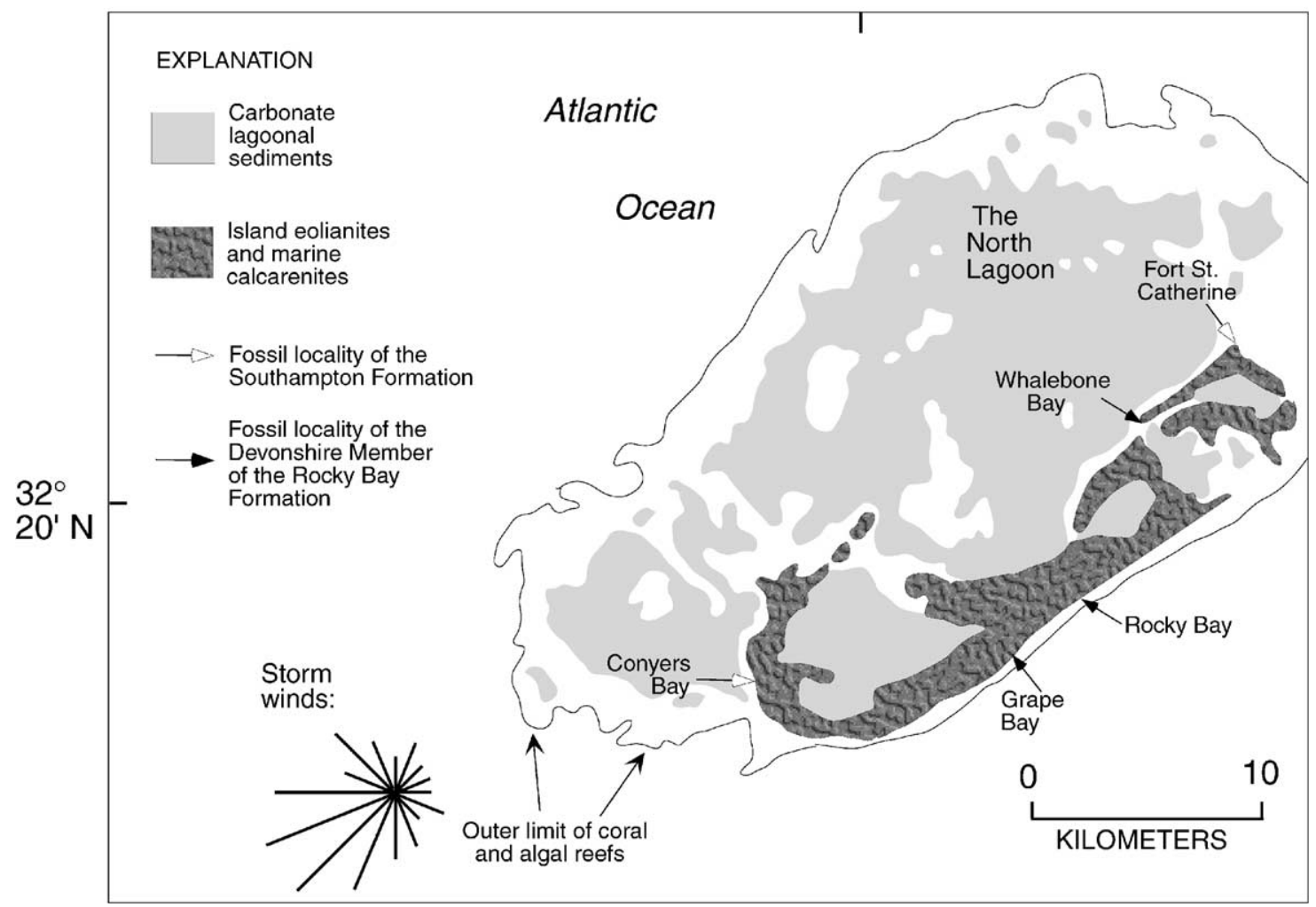

Fig. 4. Map of Bermuda showing islands, lagoonal sediments, outer limits of coral reefs, localities studied and those referred to in the text. Base map from Vacher et al. (1989).

to have experienced closed-system conditions. On the other hand, Edwards et al. (1997) showed that corals with initial ${ }^{234} \mathrm{U} /{ }^{238} \mathrm{U}$ activity values as high as 1.166 showed concordance between ${ }^{230} \mathrm{Th}$ and ${ }^{231} \mathrm{~Pa}$ ages. In this study, we consider as "reliable" any corals with initial ${ }^{234} \mathrm{U} /{ }^{238} \mathrm{U}$ activity values from 1.145 to 1.159 , similar to the range used by Stirling et al. (1998).

\section{Uranium-series ages}

\subsection{Oahu}

The Waimanalo Formation is well exposed at a number of localities around Oahu and corals were collected from many exposures. On the north shore of Oahu, east of Kaena Point, extensive outcrops of the Waimanalo Formation are easily mapped over more than $3 \mathrm{~km}$ of coastline (Figs. 5 and 6). Corals in the Waimanalo Formation are generally well preserved, show little recrystallization to calcite, and their potential for yielding reliable ages is high. On Oahu, approximately half of the analyzed corals met all closed system requirements (described above) and therefore can be considered to have reliable ages. These corals have a range of ages that spans $\sim 133-113 \mathrm{ka}$ (Table 1), which is very similar to the range reported by Szabo et al. (1994).

Corals in growth position in the lower, reef facies of the Waimanalo Formation are found at Mokapu Point, Kahuku Point, and east of Kaena Point (Fig. 7). Two samples of growth-position Porites from Mokapu Point yielded relatively old apparent ages of $\sim 143$ and $\sim 130 \mathrm{ka}$, but both had higher-than-acceptable initial ${ }^{234} \mathrm{U} /{ }^{238} \mathrm{U}$ activity values. At Kahuku Point, a previous study showed that growth-position Porites samples yielded acceptable initial ${ }^{234} \mathrm{U} /{ }^{238} \mathrm{U}$ activity values (Szabo et al., 1994), and ages that ranged from $114.1 \pm 1.8$ to $121.7 \pm 1.5 \mathrm{ka}$. New analyses of Kahuku Point corals agree with the earlier data: two samples of growth position Porites yielded ages of $113 \pm 0.7$ and $121 \pm 1.3 \mathrm{ka}$ and acceptable initial ${ }^{234} \mathrm{U} /{ }^{238} \mathrm{U}$ activity values.

Some of the best exposures of the Waimanalo Formation are present along the north shore of Oahu, east of Kaena Point (Fig. 5). This area was mapped in detail by Muhs and Szabo (1994) and is shown in Fig. 6. Three new analyses of growth-position Porites from these exposures gave ages ranging from $\sim 126$ to $\sim 118 \mathrm{ka}$, all with acceptable initial ${ }^{234} \mathrm{U} /{ }^{238} \mathrm{U}$ activity values. This range of values is somewhat older than the $\sim 110-121$ ka range reported by Szabo et al. (1994), but 
Table 1

$\mathrm{U}$ and Th concentrations, isotopic activity ratios, and ages of corals from Oahu, Hawaii. "Reliable" ages and their initial U isotopic ratios are given in bold type

\begin{tabular}{|c|c|c|c|c|c|c|c|c|c|c|c|c|c|}
\hline Sample No. & Genus & Locality & $\mathrm{U}(\mathrm{ppm})$ & ${ }^{232} \mathrm{Th}(\mathrm{ppm})$ & ${ }^{234} \mathrm{U} /{ }^{238} \mathrm{U}$ & Error & ${ }^{230} \mathrm{Th} /{ }^{238} \mathrm{U}$ & Error & ${ }^{230} \mathrm{Th} /{ }^{232} \mathrm{Th}$ & $\begin{array}{l}{ }^{230} \mathrm{Th} /{ }^{238} \mathrm{U} \\
\text { Age (ka) }\end{array}$ & Error & $\begin{array}{l}{ }_{\text {init }}^{234} \mathrm{U}^{238} \mathrm{U} \\
\text { in }\end{array}$ & Error \\
\hline HA-7-X & Pocillopora & Kahe Point & 2.41 & 0.0101 & 1.1154 & 0.0015 & 0.7508 & 0.0022 & 542 & 118.2 & 0.7 & 1.1613 & 0.0019 \\
\hline HA-7-X dup & Pocillopora & Kahe Point & 2.40 & 0.0093 & 1.1163 & 0.0025 & 0.7474 & 0.0025 & 584 & 117.0 & 0.9 & 1.1620 & 0.0032 \\
\hline HA-7-Y & Porites & Kahe Point & 2.71 & 0.0038 & 1.1052 & 0.0019 & 0.7478 & 0.0046 & 1621 & 119.5 & 1.4 & 1.1477 & 0.0025 \\
\hline HA-7-Y dup & Porites & Kahe Point & 2.68 & 0.0038 & 1.1063 & 0.0032 & 0.7489 & 0.0028 & 1595 & 119.6 & 1.1 & 1.1492 & 0.0042 \\
\hline HA-7-Y dup \#2 & Porites & Kahe Point & 2.69 & 0.0034 & 1.1083 & 0.0018 & 0.7497 & 0.0015 & 1797 & 119.4 & 0.6 & 1.1519 & 0.0023 \\
\hline HA-3-A & Porites & Alala Point & 2.69 & 0.0002 & 1.1077 & 0.0013 & 0.7491 & 0.0106 & 33430 & 119.4 & 3.0 & 1.1511 & 0.0022 \\
\hline HA-3-A dup & Porites & Alala Point & 2.73 & 0.0001 & 1.1092 & 0.0018 & 0.7578 & 0.0015 & 83510 & 121.5 & 0.6 & 1.1541 & 0.0023 \\
\hline HA-3-B & Porites & Alala Point & 2.76 & 0.0006 & 1.1085 & 0.0016 & 0.7952 & 0.0021 & 11224 & 133.0 & 0.8 & 1.1582 & 0.0021 \\
\hline HA-3-B dup & Porites & Alala Point & 2.79 & 0.0003 & 1.1084 & 0.0043 & 0.7997 & 0.0026 & 20369 & 134.5 & 1.4 & 1.1587 & 0.0058 \\
\hline HA-3-C & Porites & Alala Point & 2.79 & 0.0006 & 1.1104 & 0.0014 & 0.7925 & 0.0020 & 11606 & 131.7 & 0.7 & 1.1603 & 0.0019 \\
\hline HA-3-D & Porites & Alala Point & 2.64 & 0.0002 & 1.1109 & 0.0020 & 0.7871 & 0.0023 & 37321 & 129.9 & 0.9 & 1.1603 & 0.0027 \\
\hline HA-9-A & Pavona & Kaena Pt. State Park & 2.86 & 0.0006 & 1.1063 & 0.0021 & 0.7757 & 0.0018 & 11897 & 127.5 & 0.8 & 1.1525 & 0.0028 \\
\hline HA-9-B & Pocillopora & Kaena Pt. State Park & 2.71 & 0.0001 & 1.1089 & 0.0018 & 0.7372 & 0.0019 & 48562 & 115.8 & 0.6 & 1.1512 & 0.0023 \\
\hline HA-9-C & Pocillopora & Kaena Pt. State Park & 2.49 & 0.0002 & 1.1114 & 0.0013 & 0.7468 & 0.0029 & 33663 & 117.9 & 0.8 & 1.1556 & 0.0018 \\
\hline HA-9-E & Pocillopora & Kaena Pt. State Park & 2.47 & 0.0002 & 1.1178 & 0.0060 & 0.7276 & 0.0017 & 27087 & 111.5 & 1.2 & 1.1615 & 0.0078 \\
\hline HA-9-E dup & Pocillopora & Kaena Pt. State Park & 2.47 & 0.0001 & 1.1191 & 0.0017 & 0.7439 & 0.0034 & 41277 & 115.5 & 1.0 & 1.1652 & 0.0022 \\
\hline HA-9-F & Pocillopora & Kaena Pt. State Park & 2.36 & 0.0002 & 1.1138 & 0.0026 & 0.7517 & 0.0018 & 24238 & 118.8 & 0.7 & 1.1593 & 0.0033 \\
\hline HA-9-F dup & Pocillopora & Kaena Pt. State Park & 2.34 & 0.0003 & 1.1126 & 0.0019 & 0.7601 & 0.0026 & 19466 & 121.4 & 0.9 & 1.1588 & 0.0025 \\
\hline HA-9-G & Porites & Kaena Pt. State Park & 2.58 & 0.0002 & 1.1063 & 0.0022 & 0.7457 & 0.0027 & 29897 & 118.7 & 0.9 & 1.1487 & 0.0029 \\
\hline HA-9-H & Porites & Kaena Pt. State Park & 2.86 & 0.0004 & 1.1037 & 0.0020 & 0.7461 & 0.0031 & 16043 & 119.4 & 1.0 & 1.1455 & 0.0026 \\
\hline HA-9-H dup & Porites & Kaena Pt. State Park & 2.69 & 0.0001 & 1.1084 & 0.0014 & 0.7466 & 0.0018 & 49215 & 118.5 & 0.6 & 1.1517 & 0.0019 \\
\hline HA-13-B & Porites, in situ & Kahuku Point & 2.71 & 0.0001 & 1.1121 & 0.0021 & 0.7292 & 0.0020 & 40543 & 113.0 & 0.7 & 1.1544 & 0.0027 \\
\hline HA-13-C & Porites, in situ & Kahuku Point & 2.72 & 0.0020 & 1.1105 & 0.0041 & 0.7571 & 0.0033 & 3048 & 121.0 & 1.3 & 1.1557 & 0.0054 \\
\hline HA-15-A & Pocillopora & N. shore, E. of Kaena Pt. & 2.38 & 0.0002 & 1.1143 & 0.0028 & 0.7539 & 0.0018 & 31459 & 119.3 & 0.8 & 1.1603 & 0.0036 \\
\hline HA-15-B & Pocillopora & N. shore, E. of Kaena Pt. & 2.22 & 0.0001 & 1.1348 & 0.0025 & 0.7853 & 0.0023 & 59947 & 123.6 & 0.9 & 1.1914 & 0.0033 \\
\hline HA-15-C & Pocillopora & N. shore, E. of Kaena Pt. & 2.38 & 0.0001 & 1.1608 & 0.0017 & 0.8992 & 0.0026 & 47952 & 152.8 & 1.1 & 1.2480 & 0.0024 \\
\hline HA-15-D & Pocillopora & N. shore, E. of Kaena Pt. & 2.18 & 0.0002 & 1.1218 & 0.0018 & 0.7549 & 0.0022 & 28759 & 118.0 & 0.7 & 1.1702 & 0.0023 \\
\hline HA-15-(1) & Porites & N. shore, E. of Kaena Pt. & 2.94 & 0.0002 & 1.1055 & 0.0014 & 0.7707 & 0.0021 & 42531 & 126.2 & 0.7 & 1.1508 & 0.0019 \\
\hline HA-15-(2) & Pocillopora & N. shore, E. of Kaena Pt. & 2.41 & 0.0001 & 1.1200 & 0.0020 & 0.7538 & 0.0019 & 41802 & 118.0 & 0.7 & 1.1677 & 0.0026 \\
\hline HA-15-3 & Pocillopora & N. shore, E. of Kaena Pt. & 2.29 & 0.0002 & 1.1143 & 0.0020 & 0.7392 & 0.0032 & 30636 & 115.2 & 0.9 & 1.1585 & 0.0026 \\
\hline HA-15-(4) & Porites & N. shore, E. of Kaena Pt. & 3.01 & 0.0002 & 1.1032 & 0.0019 & 0.7626 & 0.0039 & 40686 & 124.3 & 1.2 & 1.1468 & 0.0025 \\
\hline HA-15-(4) dup & Porites & N. shore, E. of Kaena Pt. & 2.75 & 0.0004 & 1.1030 & 0.0030 & 0.7550 & 0.0023 & 16812 & 122.1 & 0.9 & 1.1455 & 0.0039 \\
\hline HA-20-B & Porites, in situ & N. shore, E. of Kaena Pt. & 2.58 & 0.0002 & 1.1088 & 0.0017 & 0.7448 & 0.0018 & 32624 & 117.9 & 0.6 & 1.1520 & 0.0022 \\
\hline HA-20-(2) & Porites, in situ & N. shore, E. of Kaena Pt. & 2.72 & 0.0004 & 1.1067 & 0.0019 & 0.7483 & 0.0024 & 15907 & 119.3 & 0.8 & 1.1496 & 0.0025 \\
\hline HA-21-(1) & Porites, in situ & N. shore, E. of Kaena Pt. & 2.67 & 0.0010 & 1.1066 & 0.0015 & 0.7717 & 0.0021 & 6451 & 126.2 & 0.7 & 1.1524 & 0.0021 \\
\hline HA-19-A & Porites & Mokapu Point & 2.68 & 0.0004 & 1.1119 & 0.0012 & 0.7886 & 0.0019 & 15320 & 130.1 & 0.7 & 1.1618 & 0.0016 \\
\hline HA-19B-(1/2) & Porites & Mokapu Point & 2.48 & 0.0034 & 1.1104 & 0.0018 & 0.8273 & 0.0028 & 1809 & 143.2 & 1.1 & 1.1656 & 0.0025 \\
\hline
\end{tabular}


Table 2

$\mathrm{U}$ and Th concentrations, isotopic activity ratios, and ages of corals from Bermuda. "Reliable" ages and their initial U isotopic ratios are given in bold type

\begin{tabular}{|c|c|c|c|c|c|c|c|c|c|c|c|c|c|}
\hline Sample No. & Locality & Species & $\mathrm{U}(\mathrm{ppm})$ & ${ }^{232} \mathrm{Th}$ (ppm) & ${ }^{234} \mathrm{U} /{ }^{238} \mathrm{U}$ & Error & ${ }^{230} \mathrm{Th} /{ }^{238} \mathrm{U}$ & Error & ${ }^{230} \mathrm{Th} /{ }^{232} \mathrm{Th}$ & $\begin{array}{l}{ }^{230} \mathrm{Th} /{ }^{238} \mathrm{U} \\
\text { age (ka) }\end{array}$ & Error & $\begin{array}{l}{ }^{234} \mathrm{U} /{ }^{238} \mathrm{U} \\
\text { init }\end{array}$ & Error \\
\hline \multicolumn{14}{|c|}{ Southampton formation } \\
\hline FSC-OC-1-A & Fort St. Catherine & Oculina sp. & 2.44 & 0.0061 & 1.1137 & 0.0017 & 0.5939 & 0.0023 & 719 & 81.5 & 0.5 & 1.1432 & 0.0020 \\
\hline FSC-OC-1-B & Fort St. Catherine & Oculina sp. & 2.44 & 0.0088 & 1.1149 & 0.0018 & 0.5865 & 0.0020 & 493 & 79.9 & 0.4 & 1.1441 & 0.0022 \\
\hline FSC-OC-1-C & Fort St. Catherine & Oculina sp. & 2.71 & 0.0065 & 1.1200 & 0.0024 & 0.5911 & 0.0019 & 751 & 80.2 & 0.5 & 1.1506 & 0.0028 \\
\hline FSC-OC-1-D & Fort St. Catherine & Oculina sp. & 2.27 & 0.0061 & 1.1153 & 0.0029 & 0.6034 & 0.0031 & 676 & 83.3 & 0.7 & 1.1459 & 0.0035 \\
\hline FSC-OC-1-E & Fort St. Catherine & Oculina sp. & 2.33 & 0.0035 & 1.1226 & 0.0020 & 0.5927 & 0.0024 & 1,205 & 80.2 & 0.5 & 1.1539 & 0.0024 \\
\hline FSC-OC-1-F & Fort St. Catherine & Oculina sp. & 3.67 & 0.0055 & 1.1144 & 0.0017 & 0.5880 & 0.0018 & 1,184 & 80.3 & 0.4 & 1.1436 & 0.0020 \\
\hline FSC-OC-1-G & Fort St. Catherine & Oculina sp. & 2.93 & 0.0050 & 1.1171 & 0.0018 & 0.5834 & 0.0020 & 1,034 & 79.0 & 0.4 & 1.1465 & 0.0022 \\
\hline FSC-OC-1G dup & Fort St. Catherine & Oculina sp. & 2.92 & 0.0059 & 1.1154 & 0.0017 & 0.5841 & 0.0020 & 884 & 79.4 & 0.4 & 1.1445 & 0.0020 \\
\hline FSC-OC-1-H & Fort St. Catherine & Oculina sp. & 2.31 & 0.0040 & 1.1139 & 0.0017 & 0.6065 & 0.0033 & 1,050 & 84.0 & 0.7 & 1.1445 & 0.0021 \\
\hline FSC-OC-1-I & Fort St. Catherine & Oculina sp. & 3.06 & 0.0020 & 1.1170 & 0.0017 & 0.5851 & 0.0014 & 2,779 & 79.4 & 0.3 & 1.1466 & 0.0020 \\
\hline FSC-OC-1-J & Fort St. Catherine & Oculina sp. & 2.23 & 0.0013 & 1.1164 & 0.0016 & 0.5827 & 0.0019 & 2,974 & 79.0 & 0.4 & 1.1456 & 0.0019 \\
\hline FSC-OC-1-K & Fort St. Catherine & Oculina sp. & 2.52 & 0.0023 & 1.1165 & 0.0017 & 0.5801 & 0.0018 & 1,949 & 78.4 & 0.4 & 1.1456 & 0.0020 \\
\hline FSC-OC-1-L & Fort St. Catherine & Oculina sp. & 2.37 & 0.0021 & 1.1130 & 0.0014 & 0.5821 & 0.0019 & 2,000 & 79.2 & 0.4 & 1.1414 & 0.0018 \\
\hline FSC-OC-1-M & Fort St. Catherine & Oculina sp. & 2.58 & 0.0017 & 1.1161 & 0.0017 & 0.5789 & 0.0017 & 2,629 & 78.3 & 0.4 & 1.1450 & 0.0020 \\
\hline FSC-OC-1-N & Fort St. Catherine & Oculina sp. & 2.54 & 0.0019 & 1.1177 & 0.0021 & 0.5925 & 0.0040 & 2,431 & 80.8 & 0.8 & 1.1480 & 0.0026 \\
\hline FSC-OC-1-O & Fort St. Catherine & Oculina sp. & 2.76 & 0.0023 & 1.1078 & 0.0017 & 0.5791 & 0.0014 & 2,108 & 79.2 & 0.3 & 1.1350 & 0.0020 \\
\hline FSC-OC-1-P & Fort St. Catherine & Oculina sp. & 2.77 & 0.0029 & 1.1139 & 0.0017 & 0.5929 & 0.0012 & 1,721 & 81.3 & 0.3 & 1.1434 & 0.0020 \\
\hline FSC-OC-1-Q & Fort St. Catherine & Oculina sp. & 2.95 & 0.0032 & 1.1146 & 0.0018 & 0.5874 & 0.0016 & 1,639 & 80.1 & 0.4 & 1.1438 & 0.0022 \\
\hline \multicolumn{14}{|c|}{ Rocky bay formation } \\
\hline GB-2A & Grape Bay & Siderastrea $\mathrm{sp}$. & 3.08 & 0.0172 & 1.1101 & 0.0018 & 0.7572 & 0.0022 & 412 & 121.1 & 0.7 & 1.1553 & 0.0024 \\
\hline GB-3 & Grape Bay & Oculina sp. & 1.44 & 0.0015 & 1.1248 & 0.0021 & 0.7683 & 0.0063 & 2,300 & 121.0 & 1.8 & 1.1758 & 0.0029 \\
\hline GB-4 & Grape Bay & Oculina sp. & 1.54 & 0.0029 & 1.1743 & 0.0022 & 0.7103 & 0.0058 & 1,143 & 97.9 & 1.3 & 1.2300 & 0.0029 \\
\hline GB-6 & Grape Bay & Colpophyllia sp. & 2.82 & 0.0012 & 1.1073 & 0.0017 & 0.7389 & 0.0030 & 5,067 & 116.6 & 0.9 & 1.1493 & 0.0022 \\
\hline GB-7 & Grape Bay & Montastrea cavernosa & 2.75 & 0.0009 & 1.1077 & 0.0021 & 0.7274 & 0.0030 & 6,834 & 113.4 & 0.9 & 1.1485 & 0.0027 \\
\hline GB-9 & Grape Bay & Siderastrea siderea & 3.02 & 0.0009 & 1.1103 & 0.0017 & 0.7477 & 0.0029 & 7,982 & 118.4 & 0.9 & 1.1543 & 0.0022 \\
\hline GB-10 & Grape Bay & Colpophyllia natans & 2.81 & 0.0020 & 1.1073 & 0.0017 & 0.7471 & 0.0019 & 3,152 & 118.9 & 0.6 & 1.1503 & 0.0022 \\
\hline GB-11 & Grape Bay & Montastrea cavernosa & 2.75 & 0.0013 & 1.1093 & 0.0013 & 0.7715 & 0.0026 & 4,851 & 125.5 & 0.8 & 1.1560 & 0.0018 \\
\hline \multicolumn{14}{|l|}{ Belmont formation } \\
\hline GB-12 & Grape Bay & Oculina sp. & 2.44 & 0.0003 & 1.0889 & 0.0020 & 0.9314 & 0.0027 & 26,892 & 198.8 & 2.0 & 1.1562 & 0.0030 \\
\hline GB-13 & Grape Bay & Oculina sp. & 2.54 & 0.0002 & 1.0842 & 0.0020 & 0.9299 & 0.0027 & 30,458 & 200.8 & 2.0 & 1.1487 & 0.0030 \\
\hline
\end{tabular}


Table 3

Comparison of U-series ages and U activity ratios using old and new half-lives. "Reliable" ages and their initial U isotopic ratios are given in bold type

\begin{tabular}{|c|c|c|c|c|c|c|c|c|}
\hline Sample\# & $\begin{array}{l}{ }^{230} \mathrm{Th} /{ }^{238} \mathrm{U} \\
\text { age }(\mathrm{ka}) \\
\text { (calculated }\end{array}$ & $\begin{array}{l}\text { Error } \\
\text { old half }\end{array}$ & $\begin{array}{l}{ }^{234} \mathrm{U} /{ }^{238} \mathrm{U} \\
\text { init }\end{array}$ & Error & $\begin{array}{l}{ }^{230} \mathrm{Th} /{ }^{238} \mathrm{U} \\
\text { age }(\mathrm{ka}) \\
\text { (calculated }\end{array}$ & $\begin{array}{l}\text { Error } \\
\text { new hal }\end{array}$ & $\begin{array}{l}{ }^{234} U /{ }^{238} U \\
\text { init }\end{array}$ & Error \\
\hline \multicolumn{9}{|c|}{ Waimanalo formation, Oahu, Hawaii } \\
\hline HA-7-X & 118.2 & 0.7 & 1.1613 & 0.0019 & 117.8 & 0.7 & 1.1610 & 0.0019 \\
\hline HA-7-X dup & 117.0 & 0.9 & 1.1620 & 0.0032 & 116.7 & 0.9 & 1.1617 & 0.0032 \\
\hline HA-7-Y & 119.5 & 1.4 & 1.1477 & 0.0025 & 119.1 & 1.4 & 1.1474 & 0.0025 \\
\hline HA-7-Y dup & 119.6 & 1.1 & 1.1492 & 0.0042 & 119.2 & 1.1 & 1.1489 & 0.0042 \\
\hline HA-7-Y dup \#2 & 119.4 & 0.6 & 1.1519 & 0.0023 & 119.0 & 0.6 & 1.1516 & 0.0023 \\
\hline HA-3-A & 119.4 & 3.0 & 1.1511 & 0.0022 & 119.0 & 3.0 & 1.1508 & 0.0022 \\
\hline HA-3-A dup & 121.5 & 0.6 & 1.1541 & 0.0023 & 121.1 & 0.6 & 1.1538 & 0.0023 \\
\hline HA-3-B & 133.0 & 0.8 & 1.1582 & 0.0021 & 132.5 & 0.8 & 1.1579 & 0.0021 \\
\hline HA-3-B dup & 134.5 & 1.4 & 1.1587 & 0.0058 & 134.0 & 1.4 & 1.1583 & 0.0058 \\
\hline HA-3-C & 131.7 & 0.7 & 1.1603 & 0.0019 & 131.2 & 0.7 & 1.1599 & 0.0019 \\
\hline HA-3-D & 129.9 & 0.9 & 1.1603 & 0.0027 & 129.4 & 0.9 & 1.1599 & 0.0027 \\
\hline HA-9-A & 127.5 & 0.8 & 1.1525 & 0.0028 & 127.1 & 0.7 & 1.1522 & 0.0028 \\
\hline HA-9-B & 115.8 & 0.6 & 1.1512 & 0.0023 & 115.4 & 0.6 & 1.1509 & 0.0023 \\
\hline HA-9-C & 117.9 & 0.8 & 1.1556 & 0.0018 & 117.5 & 0.8 & 1.1553 & 0.0018 \\
\hline HA-9-E & 111.5 & 1.2 & 1.1615 & 0.0078 & 111.1 & 1.2 & 1.1612 & 0.0078 \\
\hline HA-9-E dup & 115.5 & 1.0 & 1.1652 & 0.0022 & 115.2 & 1.0 & 1.1649 & 0.0022 \\
\hline HA-9-F & 118.8 & 0.7 & 1.1593 & 0.0033 & 118.4 & 0.7 & 1.1590 & 0.0033 \\
\hline HA-9-F dup & 121.4 & 0.9 & 1.1588 & 0.0025 & 121.0 & 0.9 & 1.1585 & 0.0025 \\
\hline HA-9-G & 118.7 & 0.9 & 1.1487 & 0.0029 & 118.3 & 0.9 & 1.1484 & 0.0029 \\
\hline HA-9-H & 119.4 & 1.0 & 1.1455 & 0.0026 & 119.0 & 1.0 & 1.1452 & 0.0026 \\
\hline HA-9-H dup & 118.5 & 0.6 & 1.1517 & 0.0019 & 118.1 & 0.6 & 1.1514 & 0.0019 \\
\hline HA-13-B & 113.0 & 0.7 & 1.1544 & 0.0027 & 112.7 & 0.7 & 1.1541 & 0.0027 \\
\hline HA-13-C & 121.0 & 1.3 & 1.1557 & 0.0054 & 120.6 & 1.3 & 1.1554 & 0.0054 \\
\hline HA-15-A & 119.3 & 0.8 & 1.1603 & 0.0036 & 118.9 & 0.8 & 1.1600 & 0.0036 \\
\hline HA-15-B & 123.6 & 0.9 & 1.1914 & 0.0033 & 123.2 & 0.9 & 1.1910 & 0.0033 \\
\hline HA-15-C & 152.8 & 1.1 & 1.248 & 0.0024 & 152.1 & 1.1 & 1.2472 & 0.0024 \\
\hline HA-15-D & 118.0 & 0.7 & 1.1702 & 0.0023 & 117.6 & 0.7 & 1.1699 & 0.0023 \\
\hline HA-15-(1) & 126.2 & 0.7 & 1.1508 & 0.0019 & 125.7 & 0.7 & 1.1505 & 0.0019 \\
\hline HA-15-(2) & 118.0 & 0.7 & 1.1677 & 0.0026 & 117.7 & 0.7 & 1.1673 & 0.0026 \\
\hline HA-15-3 & 115.2 & 0.9 & 1.1585 & 0.0026 & 114.9 & 0.9 & 1.1582 & 0.0026 \\
\hline HA-15-(4) & 124.3 & 1.2 & 1.1468 & 0.0025 & 123.9 & 1.2 & 1.1465 & 0.0025 \\
\hline HA-15-(4) dup & 122.1 & 0.9 & 1.1455 & 0.0039 & 121.7 & 0.9 & 1.1452 & 0.0039 \\
\hline HA-20-B & 117.9 & 0.6 & 1.152 & 0.0022 & 117.5 & 0.6 & 1.1517 & 0.0022 \\
\hline HA-20-(2) & 119.3 & 0.8 & 1.1496 & 0.0025 & 119.0 & 0.8 & 1.1493 & 0.0025 \\
\hline HA-21-(1) & 126.2 & 0.7 & 1.1524 & 0.0021 & 125.8 & 0.7 & 1.1521 & 0.0021 \\
\hline HA-19-A & 130.1 & 0.7 & 1.1618 & 0.0016 & 129.6 & 0.7 & 1.1614 & 0.0016 \\
\hline HA-19B-(1/2) & 143.2 & 1.1 & 1.1656 & 0.0025 & 142.6 & 1.1 & 1.1652 & 0.0025 \\
\hline \multicolumn{9}{|c|}{ Southampton formation, Bermuda } \\
\hline FSC-OC-1-A & 81.5 & 0.5 & 1.1432 & 0.0020 & 81.4 & 0.5 & 1.1430 & 0.0020 \\
\hline FSC-OC-1-B & 79.9 & 0.4 & 1.1441 & 0.0022 & 79.7 & 0.4 & 1.1440 & 0.0022 \\
\hline FSC-OC-1-C & 80.2 & 0.5 & 1.1506 & 0.0028 & 80.1 & 0.5 & 1.1505 & 0.0028 \\
\hline FSC-OC-1-D & 83.3 & 0.7 & 1.1459 & 0.0035 & 83.1 & 0.7 & 1.1458 & 0.0035 \\
\hline FSC-OC-1-E & 80.2 & 0.5 & 1.1539 & 0.0024 & 80.1 & 0.5 & 1.1538 & 0.0024 \\
\hline FSC-OC-1-F & 80.3 & 0.4 & 1.1436 & 0.0020 & 80.1 & 0.4 & 1.1435 & 0.0020 \\
\hline FSC-OC-1-G & 79.0 & 0.4 & 1.1465 & 0.0022 & 78.9 & 0.4 & 1.1463 & 0.0022 \\
\hline FSC-OC-1G dup & 79.4 & 0.4 & 1.1445 & 0.0020 & 79.2 & 0.4 & 1.1443 & 0.0020 \\
\hline FSC-OC-1-H & 84.0 & 0.7 & 1.1445 & 0.0021 & 83.9 & 0.7 & 1.1444 & 0.0021 \\
\hline FSC-OC-1-I & 79.4 & 0.3 & 1.1466 & 0.0020 & 79.2 & 0.3 & 1.1464 & 0.0020 \\
\hline FSC-OC-1-J & 79.0 & 0.4 & 1.1456 & 0.0019 & 78.8 & 0.4 & 1.1454 & 0.0019 \\
\hline FSC-OC-1-K & 78.4 & 0.4 & 1.1456 & 0.0020 & 78.3 & 0.4 & 1.1454 & 0.0020 \\
\hline FSC-OC-1-L & 79.2 & 0.4 & 1.1414 & 0.0018 & 79.1 & 0.4 & 1.1413 & 0.0018 \\
\hline FSC-OC-1-M & 78.3 & 0.4 & 1.1450 & 0.0020 & 78.1 & 0.4 & 1.1448 & 0.0020 \\
\hline FSC-OC-1-N & 80.8 & 0.8 & 1.1480 & 0.0026 & 80.6 & 0.8 & 1.1478 & 0.0026 \\
\hline FSC-OC-1-O & 79.2 & 0.3 & 1.1350 & 0.0020 & 79.1 & 0.3 & 1.1348 & 0.0020 \\
\hline FSC-OC-1-P & 81.3 & 0.3 & 1.1434 & 0.0020 & 81.1 & 0.3 & 1.1433 & 0.0020 \\
\hline FSC-OC-1-Q & 80.1 & 0.4 & 1.1438 & 0.0022 & 80.0 & 0.4 & 1.1436 & 0.0022 \\
\hline \multicolumn{9}{|c|}{ Rocky bay formation, Bermuda } \\
\hline GB-2A & 121.1 & 0.7 & 1.1553 & 0.0024 & - & - & - & - \\
\hline GB-3 & 121.0 & 1.8 & 1.1758 & 0.0029 & 120.7 & 1.8 & 1.1755 & 0.0029 \\
\hline
\end{tabular}


Table 3 (continued)

\begin{tabular}{|c|c|c|c|c|c|c|c|c|}
\hline Sample\# & $\begin{array}{l}{ }^{230} \mathrm{Th} /{ }^{238} \mathrm{U} \\
\text { age }(\mathrm{ka}) \\
\text { (calculated }\end{array}$ & $\begin{array}{l}\text { Error } \\
\text { ld half- }\end{array}$ & $\begin{array}{l}{ }^{234} \mathrm{U} /{ }^{238} \mathrm{U} \\
\text { init }\end{array}$ & Error & $\begin{array}{l}{ }^{230} \mathrm{Th} /{ }^{238} \mathrm{U} \\
\text { age }(\mathrm{ka}) \\
\text { (calculated }\end{array}$ & $\begin{array}{l}\text { Error } \\
\text { new half }\end{array}$ & $\begin{array}{l}{ }^{234} \mathrm{U} /{ }^{238} \mathrm{U} \\
\text { init }\end{array}$ & Error \\
\hline GB-4 & 97.9 & 1.3 & 1.2300 & 0.0029 & 97.7 & 1.3 & 1.2297 & 0.0029 \\
\hline GB-6 & 116.6 & 0.9 & 1.1493 & 0.0022 & 116.2 & 0.9 & 1.1490 & 0.0022 \\
\hline GB-7 & 113.4 & 0.9 & 1.1485 & 0.0027 & 113.0 & 0.9 & 1.1482 & 0.0027 \\
\hline GB-9 & 118.4 & 0.9 & 1.1543 & 0.0022 & 118.0 & 0.9 & 1.1540 & 0.0022 \\
\hline GB-10 & 118.9 & 0.6 & 1.1503 & 0.0022 & 118.5 & 0.6 & 1.1500 & 0.0022 \\
\hline GB-11 & 125.5 & 0.8 & 1.1560 & 0.0018 & 125.1 & 0.8 & 1.1556 & 0.0018 \\
\hline \multicolumn{9}{|c|}{ Belmont formation, Bermuda } \\
\hline GB-12 & 198.8 & 2.0 & 1.1562 & 0.0030 & 197.3 & 2.0 & 1.1553 & 0.0030 \\
\hline GB-13 & 200.8 & 2.0 & 1.1487 & 0.0030 & 199.3 & 2.0 & 1.1478 & 0.0030 \\
\hline
\end{tabular}

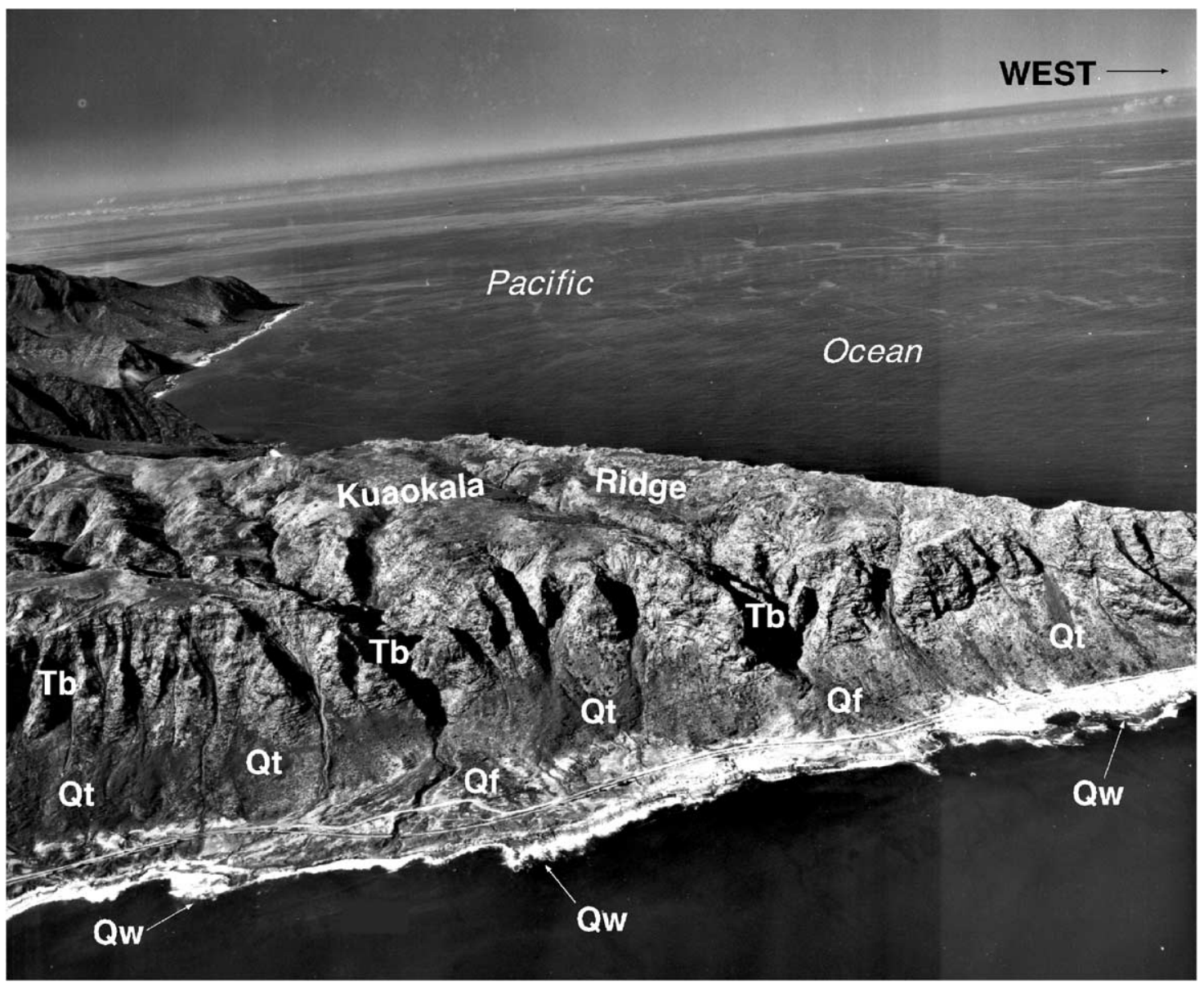

Fig. 5. Oblique aerial photograph of the Kuaokala Ridge-Kaena Point area, looking south, showing the Waimanalo Formation (Qw), overlying talus deposits (Qt) and alluvial fan deposits (Qf) and Tertiary basalt (Tb).

their analyses had larger (up to $3.8 \mathrm{ka}$ ) analytical uncertainties. The latter workers also did not analyze corals from the conglomerate facies of the Waimanalo Formation east of Kaena Point. Although we analyzed numerous specimens from the conglomerate facies, only one Pocillopora specimen and two Porites yielded acceptable initial ${ }^{234} \mathrm{U} /{ }^{238} \mathrm{U}$ activity values. The Pocillopora clast gave an age of $\sim 115 \mathrm{ka}$, and the Porites clasts gave ages of $\sim 122$ and $\sim 126 \mathrm{ka}$. Corals are better preserved in the conglomerate facies of the Waimanalo Formation southeast of Kaena Point, near Kaena Point State Park. Six specimens from the latter locality gave ages with acceptable initial ${ }^{234} \mathrm{U} /{ }^{238} \mathrm{U}$ activity values. Two Porites clasts both gave ages of $\sim 118-119 \mathrm{ka}$ and four Pocillopora clasts gave ages ranging from $\sim 116$ to $\sim 127 \mathrm{ka}$. 


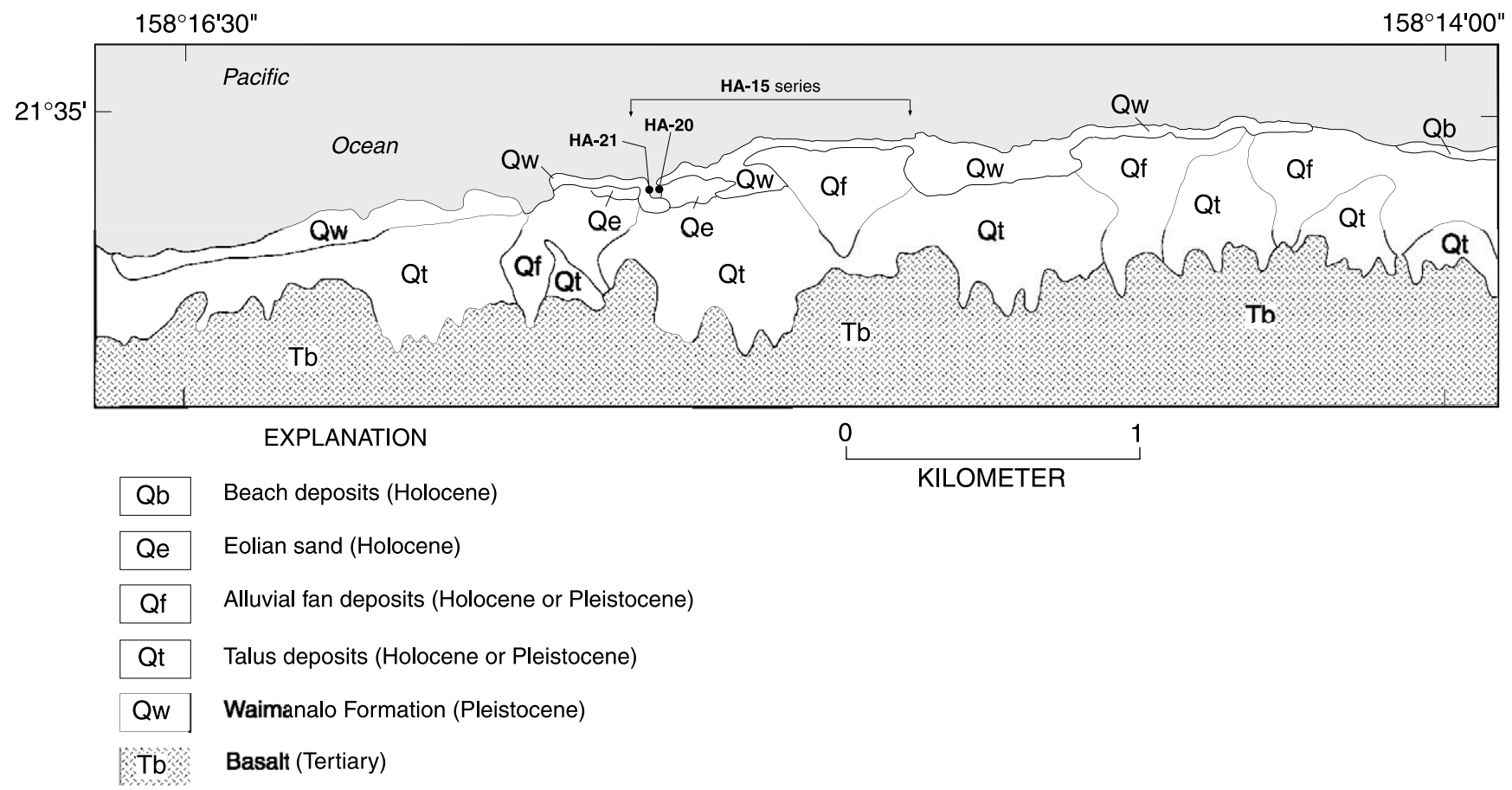

Fig. 6. Surficial geologic map of a part of the north shore of Oahu illustrating the distribution of the Waimanalo Formation shown in Fig. 5 and adjacent areas and fossil coral localities. Redrawn from Muhs and Szabo (1994).

Szabo et al. (1994) reported some of the oldest Waimanalo Formation corals at a locality near Alala Point. New analyses agree with the earlier results. Two Porites from the reef limestone at Alala Point yielded ages of $\sim 121$ and $\sim 133 \mathrm{ka}$. A third sample gave an age of $\sim 132 \mathrm{ka}$, with a slightly higher-than-acceptable initial ${ }^{234} \mathrm{U} /{ }^{238} \mathrm{U}$ activity value of 1.160 . This age may be $\sim 2 \mathrm{ka}$ too old if the model of Gallup et al. (1994) is correct.

U-series ages of corals from Kahe Point were reported by Easton and $\mathrm{Ku}$ (1981), Muhs and Szabo (1994) and Szabo et al. (1994). Kahe Point is important because it has one of the richest Last-Interglacial molluscan faunas on Oahu (Kosuge, 1969). The locality is also of interest because older ages ( $>130 \mathrm{ka}$ ), done by alpha spectrometry, were reported by Easton and $\mathrm{Ku}$ (1981) and Muhs and Szabo (1994). A Pocillopora from this locality (also analyzed by Muhs and Szabo, 1994) gave an unacceptably high initial ${ }^{234} \mathrm{U} /{ }^{238} \mathrm{U}$ activity value, but duplicate analyses of a Porites sample analyzed by Muhs and Szabo (1994) gave an age of $\sim 119 \mathrm{ka}$ with an acceptable initial ${ }^{234} U /{ }^{238} \mathrm{U}$ activity value. This latter age obviously fails to confirm the possible older ages suggested by the lower-precision alpha-spectrometric ages.

\subsection{Bermuda}

Corals from Bermuda generally also show excellent preservation, and the majority of studied specimens, even those from the penultimate interglacial Belmont Formation, met all requirements for closed-system conditions (Table 2). Two Oculina specimens from the Belmont Formation at Grape Bay (Fig. 8) yielded ages of $\sim 199$ and $\sim 201 \mathrm{ka}$, both with acceptable initial ${ }^{234} \mathrm{U} /{ }^{238} \mathrm{U}$ activity values. These ages agree well with alpha-spectrometric U-series ages of $\sim 200 \mathrm{ka}( \pm 40 \mathrm{ka}$ at 2-sigma) for the Belmont Formation at other localities (Harmon et al., 1983). The new ages for the Belmont Formation also agree well with ages of Acropora palmata cobbles from a 91-m-high beach deposit in the Clermont Nose area of Barbados (Gallup et al., 1994; Edwards et al., 1997). Their reported ages of 194, 199, and $201 \mathrm{ka}$ are not significantly different from the new ages (Table 2) for the Belmont Formation.

At Grape Bay, the Devonshire marine member overlies the Belmont Formation and marks the Last Interglacial high stand of sea. The contact between the two units is well illustrated in Figs. 5-12 of Meischner et al. (1995). Soil pipes (solution channels filled with red clay) are found in the Belmont Formation at this locality (Herwitz and Muhs, 1995). The stratigraphic significance of the soil pipes is that, although truncated, they mark a period of subaerial exposure that occurred after regression of the high stand of sea represented by the Belmont Formation and before deposition of the Devonshire marine member.

Most previously published U-series analyses of Bermuda corals are from either the Devonshire marine member of the Rocky Bay Formation or what 
(a) Alala Point:

$\longleftarrow$ NORTHEAST

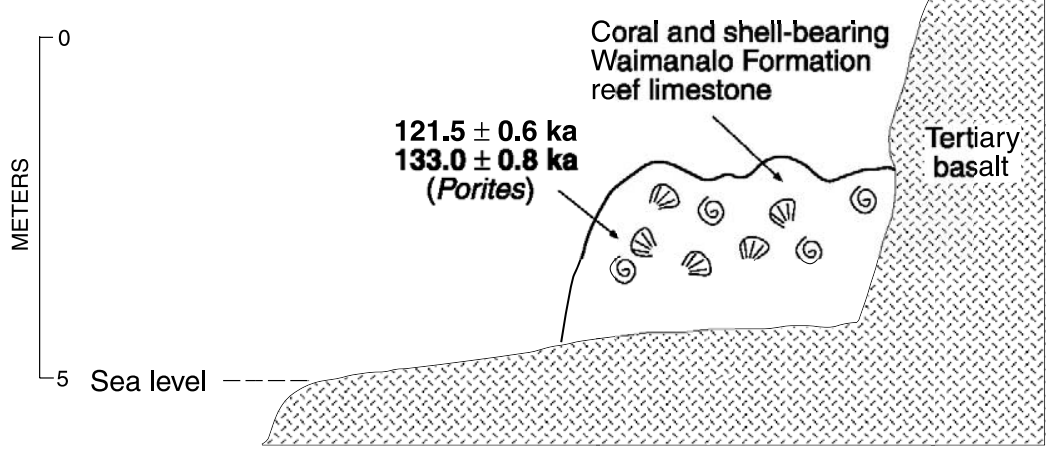

(c) North shore, east of Kaena Point:

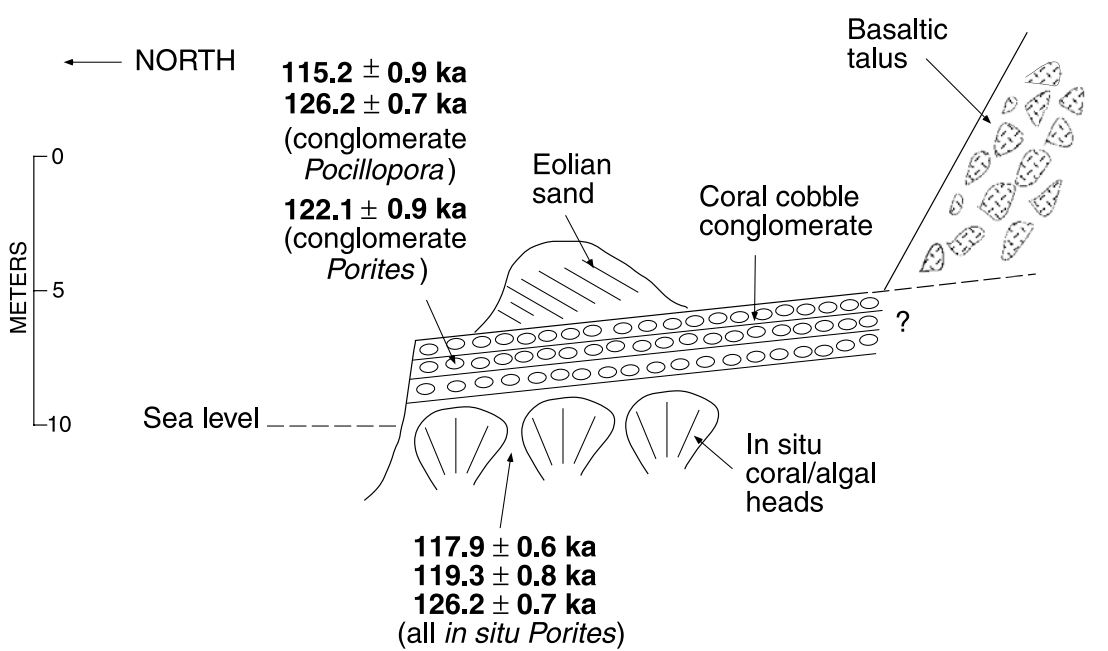

150

0 (b) Kahuku Point:

$\longleftarrow$ NORTHEAST

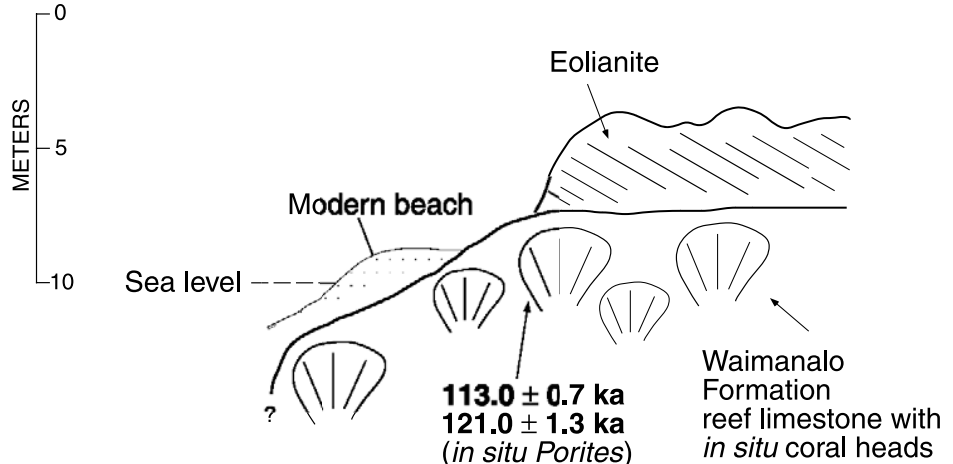

(d) Kahe Point:

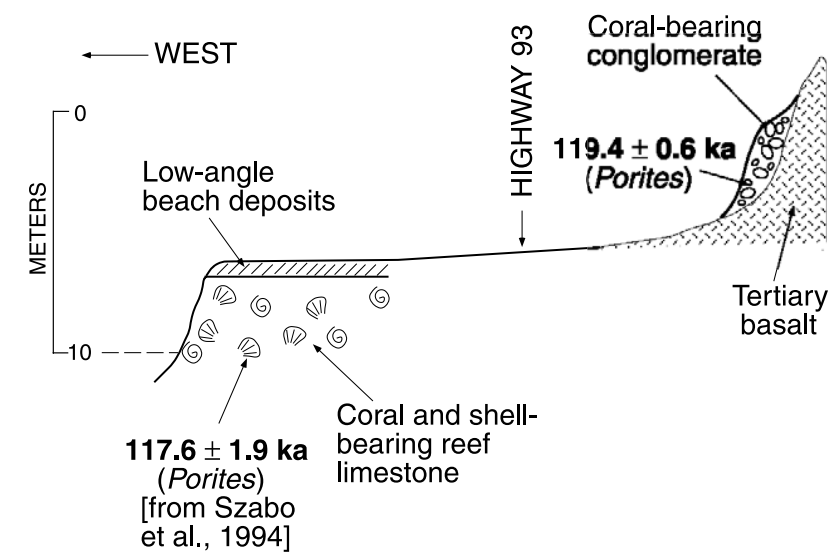

METERS

Fig. 7. Cross-sections of outcrops of the Waimanalo Formation exposed on (a) Alala Point, (b) Kahuku Point, (c) the north shore of Oahu east of Kaena Point and (d) Kahe Point (see Figs. 2 and 6 for locations), along with reliable U-series ages of corals (Table 1). Stratigraphy at Kaena Point and Kahe Point redrawn from Muhs and Szabo (1994). 
(a) Whalebone Bay:

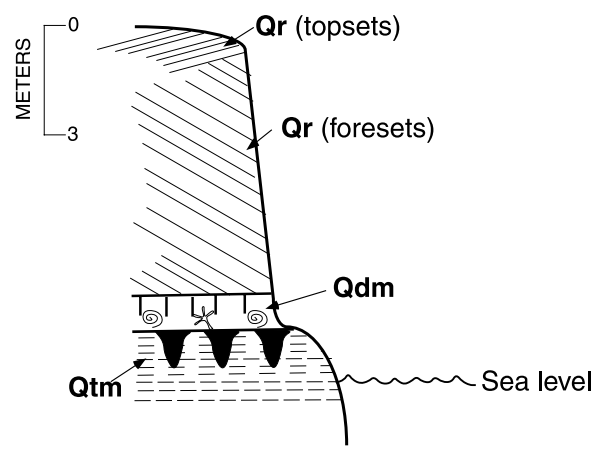

(b) Grape Bay:

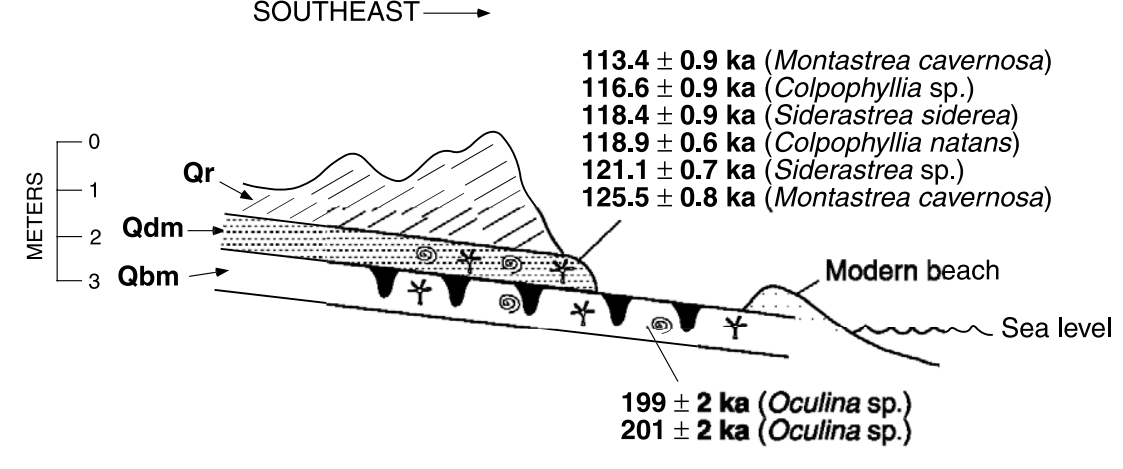

(c) Fort St. Catherine:

\section{EXPLANATION}

Qs: Southampton Formation, eolianite facies

Qr: Rocky Bay Formation, eolianite facies

Qdm: Devonshire marine member of the Rocky Bay Formation

Qbm: Belmont Formation, marine facies

Qtm: Town Hill Formation, upper member, marine facies ( $325 \mathrm{ka}$ ?)

तारा Paleosol with weakly developed
Bt horizon
Soil pipe

SOUTHEAST $\longrightarrow$

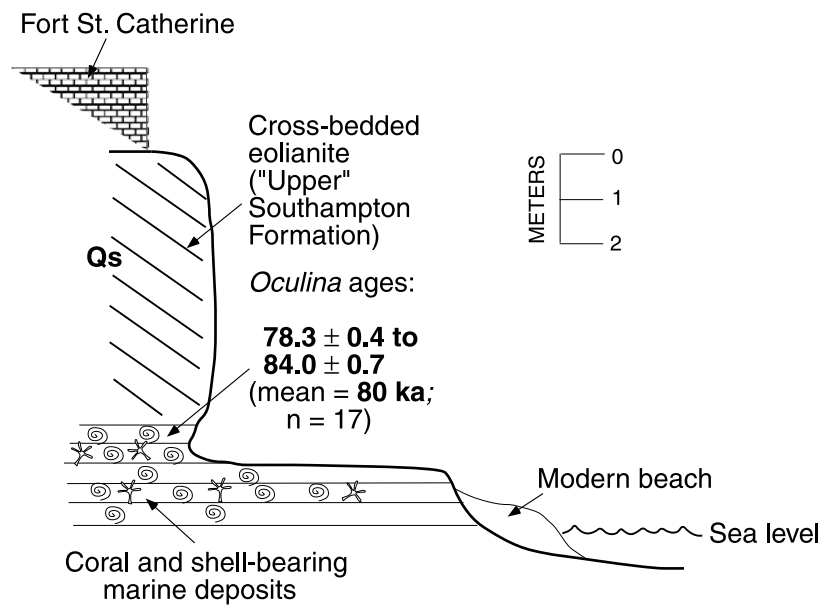

Fig. 8. Stratigraphy of sections at (a) Whalebone Bay, (b) Grape Bay, and (c) Fort St. Catherine, Bermuda and U-series ages (Table 2). See Fig. 4 for localities. Stratigraphy at Whalebone Bay and Grape Bay from Herwitz and Muhs (1995); stratigraphy at Fort St. Catherine from this study.

was previously referred to as the "Spencer's Point Formation" of Harmon et al. (1978, 1983). Previously reported ages of corals from the Devonshire member, all done by alpha spectrometry, range from $118 \pm 12$ to $134 \pm 8 \mathrm{ka}$ ( 2 sigma errors). Corals from the "Spencer's Point Formation" range from $97 \pm 12$ to $108 \pm 16 \mathrm{ka}$. Subsequent detailed mapping and stratigraphic studies suggest that the "Spencer's Point Formation" is equivalent to the Devonshire member of the Rocky Bay Formation (Vacher and Hearty, 1987; Vacher et al., 1989, 1995; Hearty et al., 1992; Hearty and Kindler, 1995; Vacher and Rowe, 1997), and the term "Spencer's Point Formation" is no longer used in Bermudan stratigraphy. Unfortunately, we did not find any corals at localities previously assigned to the Spencer's Point Formation. However, our collections at Grape Bay, as well as the earlier collections of $\mathrm{H}$. Lowenstam, yielded several corals that allow new age determinations for the Devonshire member.
New U-series analyses of corals from the Devonshire member at Grape Bay agree reasonably well with those of Harmon et al. $(1978,1983)$. Six specimens, two each of Montastrea, Siderastrea, and Colpophyllia, meet all our criteria for reliable ages. With one exception, these corals yielded $\mathrm{U}$-series ages ranging from $116.6 \pm 0.9$ to $125.5 \pm 0.8 \mathrm{ka}$, which overlap with previous alphaspectrometric ages reported by Harmon et al. (1978, 1983). One sample of Montastrea cavernosa yielded a younger age of $113.4 \pm 0.9 \mathrm{ka}$. Two Oculina samples had $\mathrm{U}$ contents of less than $2 \mathrm{ppm}$, despite having little or no evidence of recrystallization to calcite. Most colonial corals have $U$ contents of 2-4 ppm, and analyses of two modern Oculina specimens from Bermuda showed U contents of 3 ppm (Ludwig et al., 1996). In addition, the two Oculina specimens from Grape Bay yielded higherthan-acceptable initial ${ }^{234} \mathrm{U} /{ }^{238} \mathrm{U}$ values and we consider them to have experienced open system conditions.

The youngest Pleistocene deposit on Bermuda with both an eolian and marine facies is the Southampton 

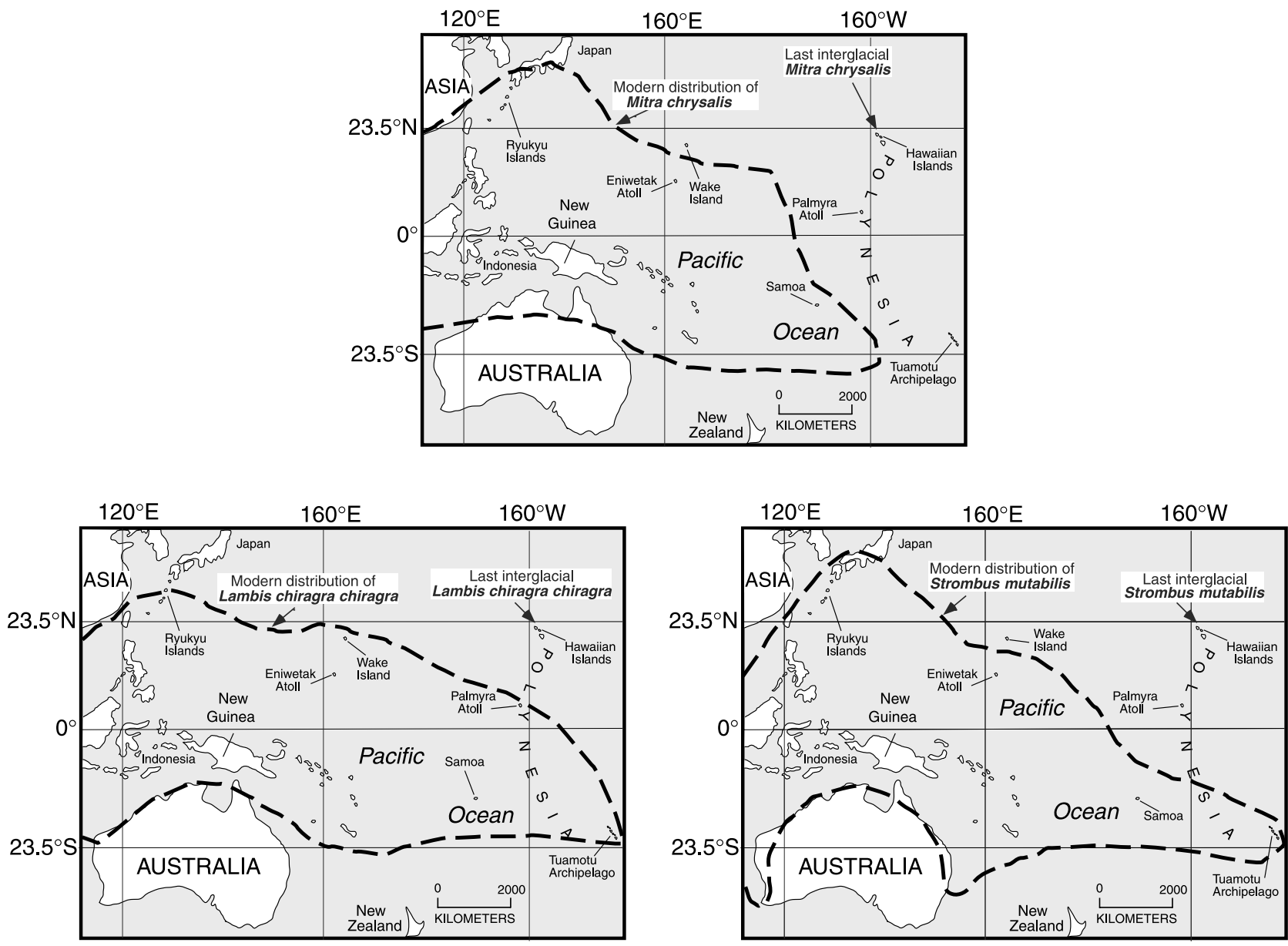

Fig. 9. Modern geographic ranges of Lambis chiragra chiragra (redrawn from Abbot, 1961), Strombus mutabilis (redrawn from Abbot, 1960), and Mitra (Nebularia) chrysalis (redrawn from Cernohorsky, 1976) in the Indo-Pacific region.

Formation (Vacher et al., 1989). A single alpha-spectrometric U-series analysis of an Oculina from the marine facies at Fort St. Catherine gave an age of $85 \pm 12 \mathrm{ka}$ (Harmon et al., 1983). They considered the deposit to have been storm-reworked and did not regard the age as an indication of a higher-than-present sea level at $\sim 85 \mathrm{ka}$. Vacher and Hearty (1989), however, challenged the storm-emplacement hypothesis of Harmon et al. (1983) with new stratigraphic and amino acid data and suggested that Fort St. Catherine was an unlikely locality for deposition by storm waves. They proposed that the deposit could indeed represent a higher-than-present sea level at $\sim 80 \mathrm{ka}$. Ludwig et al. (1996) presented new TIMS U-series ages of 77-82 ka for four Oculina specimens from Fort St. Catherine and reiterated the arguments of Vacher and Hearty (1989), agreeing that the deposit could represent a high sea stand at $\sim 80 \mathrm{ka}$. Toscano and Lundberg (1999), however, rejected the arguments of Vacher and Hearty (1989) and Ludwig et al. (1996) and returned to the storm emplacement hypothesis of Harmon et al. (1983). The possibility that the storm emplacement event occurred during the Holocene was also proposed by Toscano and Lundberg (1999).

Because of the controversy about this deposit, and because of the significant implications it has for the magnitude of past sea level, we analyzed a large suite of corals from Fort St. Catherine. Our goal was to provide a rigorous test of the storm emplacement hypothesis. If, as Toscano and Lundberg (1999) suggested, the storm emplacement event occurred during the Holocene, then the deposit at Fort St. Catherine should contain corals of any age that are found on the Bermuda Platform. Obviously, this could include corals of Holocene age, but also older corals, such as those dated at $\sim 87,94$ and $103 \mathrm{ka}$ from the upper parts of cores taken on the platform to the northwest of Fort St. Catherine (Vollbrecht, 1990).

Results of analyses of 17 Oculina fragments from Fort St. Catherine show a narrow range of ages. All but one sample (FSC-OC-1-O, which shows a lower-thanacceptable initial ${ }^{234} \mathrm{U} /{ }^{238} \mathrm{U}$ value) show excellent preservation and near-ideal criteria for closed-system 


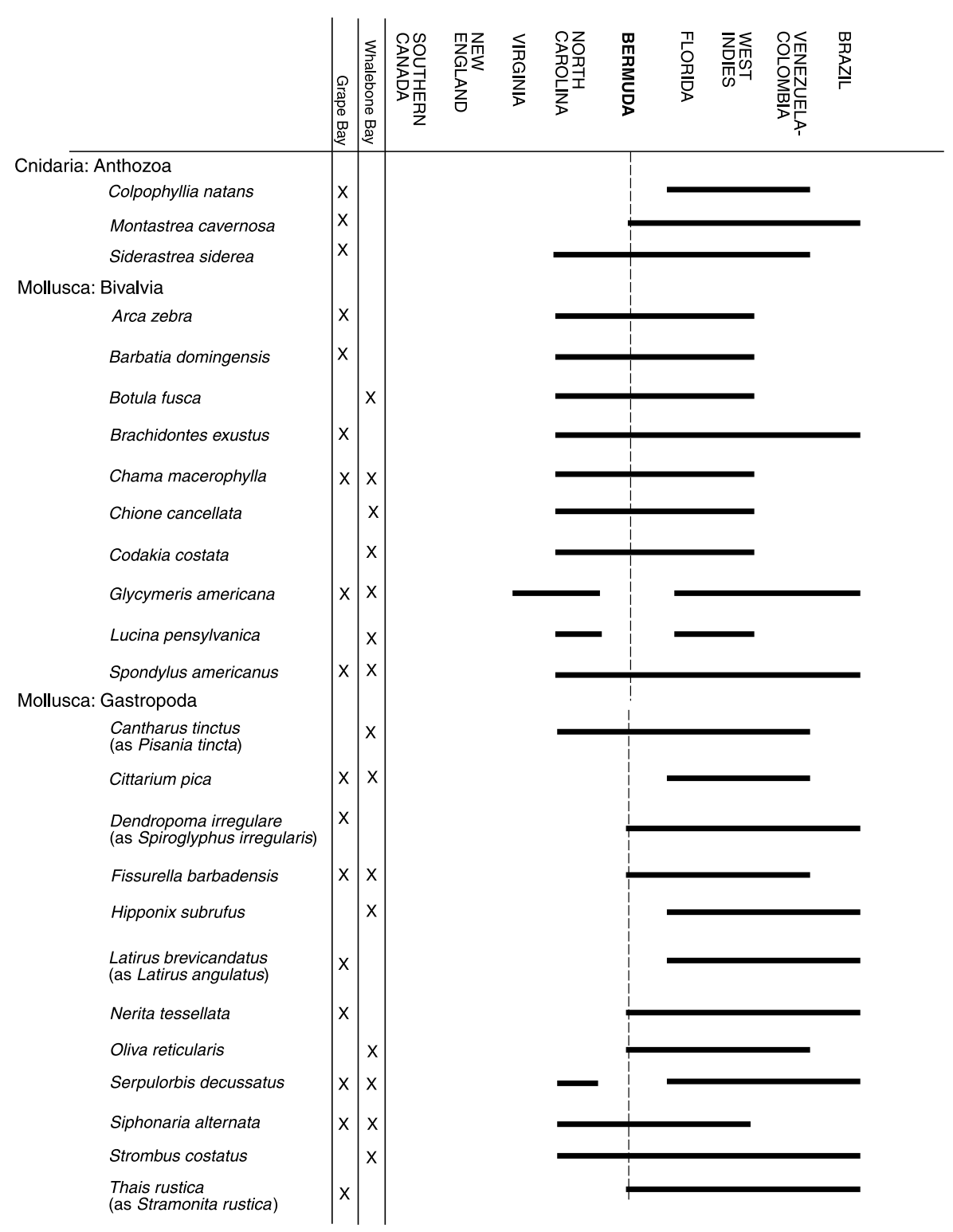

Fig. 10. Modern geographic ranges of fossils found in the Devonshire marine member of the Rocky Bay Formation of Bermuda at localities with either U-series ages of $\sim 120 \mathrm{ka}$ (from Harmon et al., 1983 and this study) or amino acid data which indicate an age of $\sim 120$ ka (Vacher and Hearty, 1989; Hearty et al., 1992). Fossil data from Epstein and Lowenstam (1953), Richards et al. (1969), and this study; see text for sources of modern geographic ranges.

conditions. All had U contents of $2-3$ ppm, no evidence of inherited $\mathrm{Th}$, and initial ${ }^{234} \mathrm{U} /{ }^{238} \mathrm{U}$ values that were indistinguishable from modern sea water values. Thus, we regard the ages from this suite of corals as very reliable. Ages range from $78.3 \pm 0.4$ to $84.0 \pm 0.7 \mathrm{ka}$ and have a mean value of $\sim 80 \mathrm{ka}$. There is no evidence of reworking of either older $(\sim 100 \mathrm{ka})$ or younger (Holocene) corals that are known to be present on the Bermuda Platform to the northwest of Fort St. Catherine. Thus, we reject the Holocene storm emplacement hypothesis. Because the corals we observed at Fort St. Catherine were not in growth position and there was not evidence of in situ patch reefs at that locality, it is possible that the deposit originated by a storm emplacement event or events that occurred during the $\sim 80 \mathrm{ka}$ high sea stand. However, the lack of older $(\sim 100$ or $\sim 125 \mathrm{ka})$ corals would tend to mitigate against this. Finally, it is possible that the deposit does not have a storm-emplacement origin but also does not represent a sea stand near present at $\sim 80 \mathrm{ka}$. Such an origin is possible if islands and coastlines at midlatitudes, closer to the positions of full-glacial ice sheets than those in tropical latitudes, experience isostatic rebound that elevates marine deposits to positions higher than where they formed initially (Stirling et al., 1998). 


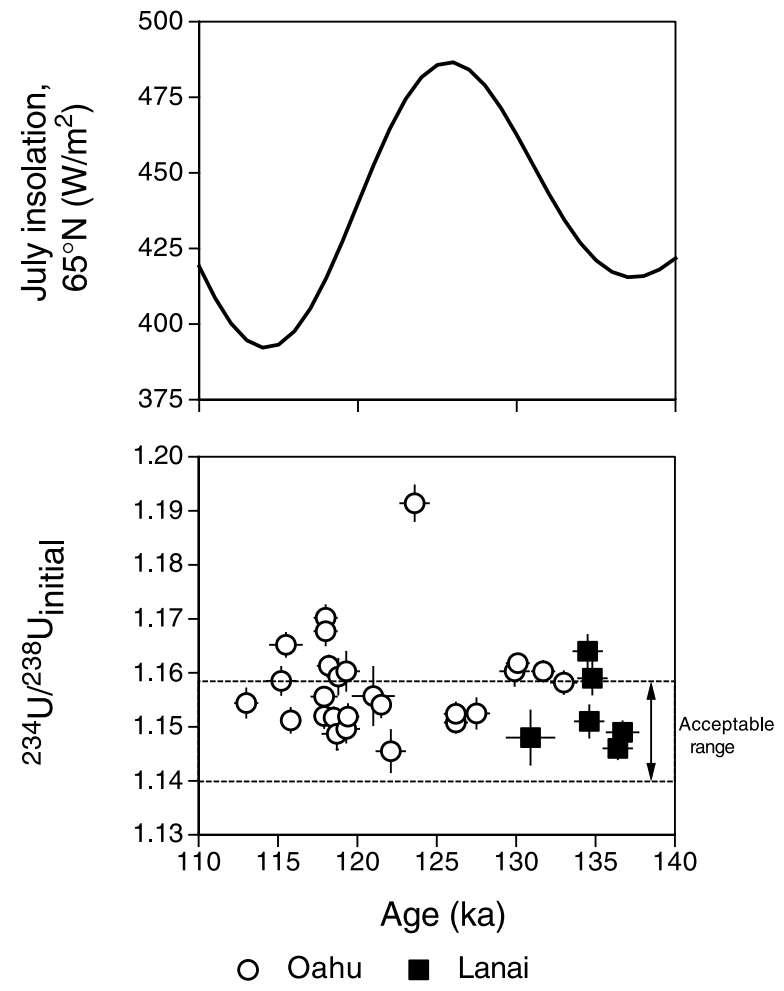

Fig. 11. Calculated initial ${ }^{234} \mathrm{U} /{ }^{238} \mathrm{U}$ activity ratios for Hawaiian corals from the Waimanalo Formation on Oahu (open circles) and from marine terrace deposits on Lanai (solid squares) plotted against their ${ }^{230} \mathrm{Th} / \mathrm{U}$ ages with 2-sigma error bars; where no bars appear, errors are smaller than the plot symbol. Also shown are July insolation values at the top of the atmosphere at $65^{\circ} \mathrm{N}$ for the period from 140 to $110 \mathrm{ka}$ (insolation data from Berger and Loutre, 1991). "Acceptable range" of initial ${ }^{234} \mathrm{U} /{ }^{238} \mathrm{U}$ activity ratios is 1.140 to 1.159 (see Discussion in text). Lanai U-series ages from Rubin et al. (2001); Oahu U-series ages from this study (Table 1). Where duplicate analyses were conducted, the sample with the smallest error is plotted.

\section{Paleozoogeography and ocean temperatures}

\subsection{Approaches}

Temperatures of the Last Interglacial period have been simulated using atmospheric general circulation models. Montoya et al. (1998) used such a model to infer significantly higher (up to $4^{\circ} \mathrm{C}$ ) summer temperatures and similar or slightly warmer winter temperatures over continental North America during the Last Interglacial period. In contrast, Last Interglacial sea surface temperatures are inferred to have increased only slightly $\left(\sim 1^{\circ} \mathrm{C}\right)$ relative to present around much of North America, with little or no difference at low latitudes and slightly greater differences at high latitudes (Montoya et al., 1998).

Paleotemperatures of the Last-Interglacial ocean also have been inferred from analysis of foraminifera in deep-sea cores. Using a global suite of cores, CLIMAP Project Members (1984) suggested that the Last-Inter-

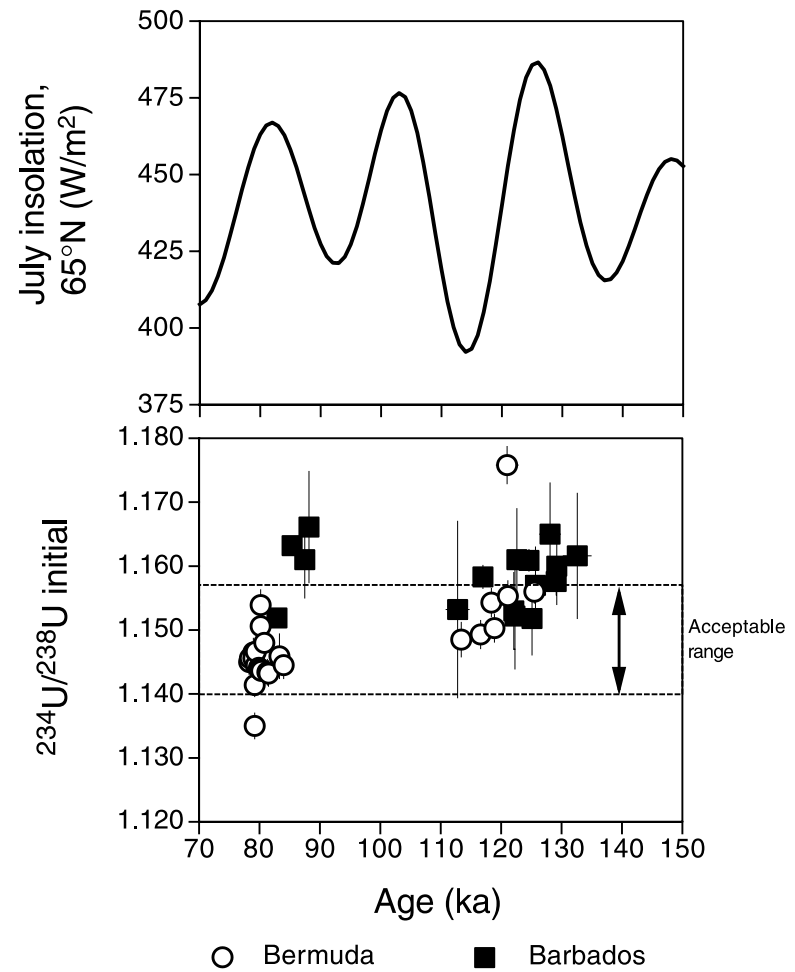

Fig. 12. Calculated initial ${ }^{234} \mathrm{U} /{ }^{238} \mathrm{U}$ activity ratios for Bermuda corals from the Devonshire marine member of the Rocky Bay Formation and the Southampton Formation plotted against their ${ }^{230} \mathrm{Th} / \mathrm{U}$ ages with $2-$ sigma error bars; where no bars appear, errors are smaller than the plot symbol. Also shown are similar data from the Rendezvous Hill ("Barbados III") and Worthing ("Barbados I") terraces from Barbados and July insolation values at the top of the atmosphere at $65^{\circ} \mathrm{N}$ for the period from 150 to $70 \mathrm{ka}$. Barbados data from Edwards et al. (1987, 1997), Bard et al. (1990), Hamelin et al. (1991), and Gallup et al. (1994); insolation data from Berger and Loutre (1991) "Acceptable range" of initial ${ }^{234} \mathrm{U} /{ }^{238} \mathrm{U}$ activity ratios as in Fig. 13.

glacial ocean may have been, overall, very similar to that of the present, but they also reported numerous anomalies, some due to sampling or data biases and others unexplained. In the CLIMAP study, however, few cores were studied from the western Atlantic, eastern Pacific, and Arctic Oceans; thus, little could be inferred about sea surface temperatures around North America. Cortijo et al. (1999) estimated sea surface temperatures from planktonic foraminifera in cores from the western Atlantic Ocean, including two from around the latitude of Bermuda. However, because few Holocene calibration cores exist in this region, uncertainties in sea surface temperature estimates are as much as $3.5^{\circ} \mathrm{C}$. In the tropical region of northwestern Australia, McCulloch and Esat (2000) used $\mathrm{Sr} / \mathrm{Ca}$ values in corals to infer Last-Interglacial sea surface temperatures little different from today's.

We use a zoogeographic approach (Kennedy, 1978, 2000; Kennedy et al., 1982, 1992) to estimating relative sea surface temperatures around Hawaii, Bermuda and North America during the Last Interglacial period. This 
method utilizes the fact that modern geographic ranges of nearshore marine invertebrates, such as mollusks, ostracodes and corals, are mainly a function of the latitudinal temperature gradient between equatorial and polar regions. Species that presently live only to the north of any fossil locality are referred to as extralimital northern species and would be indicative of cooler-thanpresent marine conditions. Conversely, any deposit with extralimital southern species can be inferred to have experienced warmer-than-present ocean temperatures. Kennedy (2000) points out that inferences of relatively warmer or cooler waters can also made from a dominance of species that are not strictly extralimital, but whose modern ranges have endpoints at or near the fossil locality of concern.

\subsection{Oahu, Hawaii}

Fossil mollusks are abundant in Pleistocene limestones of Oahu (Ostergaard, 1928; Kosuge, 1969; Kohn, 1980). The U-series ages of corals reported by Ku et al. (1974), Szabo et al. (1994), Muhs and Szabo (1994), and the present study allow identification of those fossil mollusk localities on Oahu that date to the Last Interglacial period. Of the numerous localities reported by Ostergaard (1928) and Kosuge (1969), only Kahuku Point and Kahe Point (Fig. 2) are confidently dated to the Last Interglacial period. Nevertheless, the faunas at Kahe Point and Kahuku Point are diverse enough that some inferences can be made about oceanic paleotemperatures.

Kosuge (1969) reported 69 species of mollusks, mostly gastropods, from the Kahe Point and Kahuku Point localities. Although some of these species are extinct and others are endemic to the Hawaiian Islands, the majority of species live today around Hawaii (Kay, 1979), as well as throughout much of the Indo-Pacific region. Kosuge (1969) interpreted the faunas from Oahu as indicative of warmer-than-present waters in the past, but some species distributions were not well known at the time of his study. Based on a re-examination of his species lists and newer studies of Indo-Pacific molluscan zoogeography (Cernohorsky, 1976, 1978; Kay, 1979; Warén, 1980; Kilburn, 1983; Bernard et al., 1993; Kreipl and Poppe, 1999; Abbott and Dance, 2000), we have determined that eight species do not live in Hawaiian waters today, but range elsewhere in warmer-water regions of the Indo-Pacific (Table 4). Isognomon marsupialis is known to occur today in the South China Sea and as far north as Okinawa (Bernard et al., 1993), but does not occur in Hawaii at present (Kay, 1979). Its occurrence at both Kahe Point and Kahuku Point on Oahu indicates a Last-Interglacial range extension of $\sim 7500 \mathrm{~km}$. Lambis chiragra occurs in the northern and eastern Indian Ocean, the Ryukyu Islands, northern Australia and east to the Tuamotu Archipelago (Fig. 9).
The closest documented modern record for L. chiragra is Palmyra Atoll, more than $1500 \mathrm{~km}$ to the south of Hawaii. The same is true for L. truncata, which is reported for an unspecified locality in the Waimanalo Formation by Kay (1979). Kosuge (1969) also reported the species as a fossil on Oahu, but did not specify a locality. Vexillum semifasciatum (as Pusia semifasciata) ranges only from the Red Sea to Samoa. Scalenostoma sublata (as Stilifer speciosa) has a circumtropical distribution, but is presently unknown from Hawaii. Strombus mutabilis ranges throughout the Indo-Pacific, but not in Hawaii nor any part of eastern Polynesia (Fig. 9). The closest modern record for this species is Samoa, more than $4000 \mathrm{~km}$ to the south of Hawaii. Mitra chrysalis ranges from the Red Sea and Madagascar, through the Indian Ocean to the Ryukyu Islands and Cook Islands (Fig. 9). The closest modern record of M. chrysalis is Eniwetok Atoll, more than $4000 \mathrm{~km}$ to the southwest of Hawaii. Finally, Acar plicatum ranges from South Africa, through the Indian Ocean to the Philippines, Ryukyu Islands, and northwestern Australia, but not to Hawaii. Thus, we interpret all species cited above as warm-water indicators. Two additional species reported by Kosuge (1969) from Kahe Point are Cypraea erosa Linné and Conus tulipa Linné. Although both species are found in Hawaii today (Kay, 1979), they are extremely rare. Cypraea erosa is widely distributed in the Indo-West Pacific (Kay, 1979), and although uncommon, C. tulipa is also found in the broader Indo-Pacific (Cernohorsky, 1978). Thus, both species can also be regarded as warm-water indicators, as they are apparently at or near their northern distributional limits in Hawaii. We conclude from this compilation that water temperatures around Oahu during the Last Interglacial period were at least as warm as present and probably, based on species that range only to the south and southwest of Oahu today, warmer than present, as concluded by Kosuge (1969).

\subsection{Bermuda}

The molluscan faunas from Last-Interglacial deposits on Bermuda have been well documented by Epstein and Lowenstam (1953), Richards et al. (1969) and Hearty et al. (1992). We compiled the species identified by these workers from two localities, Grape Bay and Whalebone Bay, where there are either well-documented U-series ages on corals (from Harmon et al., 1978, 1983 and this study) or amino acid ratios in mollusks similar to those in mollusks from localities with dated, co-existing corals (Vacher and Hearty, 1989 and Hearty et al., 1992). We also present the modern geographic ranges of these taxa, taken from the most recent data available in Sterrer (1986), Abbott (1974), Weisbord (1974), Abbott and Morris (1995) and web data bases from the Academy of 
Table 4

Extralimital southern species from the Waimanalo Formation, Oahu, Hawaii

\begin{tabular}{|c|c|c|c|c|}
\hline Species & Other species name & $\begin{array}{l}\text { Localities of } \\
\text { Kosuge (1969) }\end{array}$ & Modern geographic range & Source \\
\hline Isognomon marsupialis Röding & $\begin{array}{l}\text { Isognomon marsupiale } \\
\text { Röding }\end{array}$ & $\begin{array}{l}\text { Kahe Point, Kahuku } \\
\text { Point }\end{array}$ & $\begin{array}{l}\text { South China Sea, } \\
\text { Okinawa }\end{array}$ & $\begin{array}{l}\text { Bernard et al. } \\
\text { (1993) }\end{array}$ \\
\hline Lambis chiragra Linné & $\mathrm{n} / \mathrm{a}$ & Kahe Point & $\begin{array}{l}\text { Northern and eastern } \\
\text { Indian Ocean (Sri Lanka } \\
\text { to Indonesia), Ryukyu } \\
\text { Islands to northern } \\
\text { Australia and Tuamotu } \\
\text { Archipelago }\end{array}$ & $\begin{array}{l}\text { Abbot (1961), } \\
\text { Kreipl } \\
\text { and Poppe (1999) }\end{array}$ \\
\hline Lambis truncata sebae (Kiener) & $\mathrm{n} / \mathrm{a}$ & $\begin{array}{l}\text { Waimanalo high sea } \\
\text { stand from unspecified } \\
\text { locality Kosuge, 1969; } \\
\text { Kay, 1979) }\end{array}$ & $\begin{array}{l}\text { Red Sea and Persian } \\
\text { Gulf; Borneo, Philippine } \\
\text { Islands, Ryukyu Islands } \\
\text { to northern Australia and } \\
\text { Tuamotu Archipelago }\end{array}$ & Abbot (1961) \\
\hline Mitra chrysalis Reeve & $\mathrm{n} / \mathrm{a}$ & Kahuku Point & $\begin{array}{l}\text { Red Sea and Madagascar, } \\
\text { Indian Ocean to Ryukyu } \\
\text { Islands and Cook Islands }\end{array}$ & $\begin{array}{l}\text { Cernohorsky } \\
\text { (1976) }\end{array}$ \\
\hline Pusia semifasciata Lamarck & Vexillum semifasciatum & Kahe Point & Red Sea to Samoa & $\begin{array}{l}\text { Abbott and } \\
\text { Dance } \\
(2000)\end{array}$ \\
\hline Stilifer speciosa (A. Adams) & $\begin{array}{l}\text { Scalenostoma sublata } \\
\text { (Broderip) }\end{array}$ & Kahe Point & $\begin{array}{l}\text { Circumtropical, but not } \\
\text { the eastern Pacific }\end{array}$ & Warén (1980) \\
\hline Strombus mutabilis Swainson & $\mathrm{n} / \mathrm{a}$ & $\begin{array}{l}\text { Kahe Point, Kahuku } \\
\text { Point }\end{array}$ & $\begin{array}{l}\text { Entire Indo-Pacific except } \\
\text { for Hawaii and eastern } \\
\text { Polynesia }\end{array}$ & $\begin{array}{l}\text { Abbot (1960); } \\
\text { Kreipl } \\
\text { and Poppe (1999) }\end{array}$ \\
\hline Acar plicatum (Dillwyn) & $\mathrm{n} / \mathrm{a}$ & Kahe Point & $\begin{array}{l}\text { South Africa, throughout } \\
\text { Indian Ocean, Philippines, } \\
\text { Ryukyu Islands to north- } \\
\text { western Australia }\end{array}$ & Kilburn (1983) \\
\hline Conus tulipa Linné & $\mathrm{n} / \mathrm{a}$ & Kahe Point & $\begin{array}{l}\text { Uncommon in Indo- } \\
\text { Pacific; very rare in } \\
\text { Hawaii }\end{array}$ & $\begin{array}{l}\text { Cernohorsky } \\
(1978) ; \\
\text { Kay (1979) }\end{array}$ \\
\hline Cypraea erosa Linné & $\mathrm{n} / \mathrm{a}$ & Kahe Point & $\begin{array}{l}\text { Common in Indo-West } \\
\text { Pacific; very rare in } \\
\text { Hawaii }\end{array}$ & Kay (1979) \\
\hline
\end{tabular}

Natural Sciences (Philadelphia) and the Florida Museum of Natural History. Geographic ranges of mollusks in these various sources sometimes differ; where this is the case, we use the geographic range given in the more recent reference. All these sources update the modern geographic ranges of Bermudan fossils given in Richards et al. (1969).

A warm-water aspect is present in the faunal assemblage from the Last-Interglacial Devonshire marine member of Bermuda (Fig. 10). The Devonshire contains three extralimital southern gastropods (Cittarium pica, Hipponix subrufus, and Latirus brevicandatus [as Latirus angulatus]) that do not live around Bermuda today. Modern northern range endpoints of these three species are in the Florida Keys, although there is a single, poorly documented (1938) report of C. pica near St. Petersburg, Florida in the records of the Florida Museum of Natural History. The southern range endpoints of these species are either Venezuela or Brazil. Sterrer (1986) points out that in unpublished data of A.E. Verrill, C. pica has twice been introduced to
Bermuda and failed to survive. If the Florida Keys are the northernmost limit for these species, their presence in Last-Interglacial deposits of Bermuda indicates northward range extensions of $\sim 800 \mathrm{~km}$. In addition to extralimital southern mollusks, the coral Colpophyllia natans, found in the Devonshire marine deposits at Grape Bay, presently lives only as far north as the southern Florida Keys (Weisbord, 1974; Shinn et al., 1989), but as far south as Venezuela (Weisbord, 1974; Chiappone et al., 1996). Although Weisbord (1974) listed $C$. natans from Bermuda, recent study shows that it does not live around Bermuda at present (Sterrer, 1986). Thus, its presence in the Devonshire marine member indicates a Last-Interglacial northward range extension of $\sim 800 \mathrm{~km}$. Six other species, five gastropods and a coral, live no farther north than Bermuda today and have southern range endpoints off either Venezuela or Brazil. All the coral and mollusk species (with the exception of Glycymeris americana, which ranges as far north as Virginia), range no farther north than North Carolina and have southern range endpoints in the West 
Indies or off Venezuela or Brazil. We therefore interpret the Devonshire fauna to have a warmer-than-modern aspect.

\section{Discussion}

\subsection{Timing of the peak of the Last Interglacial period}

Our new U-series data for Oahu and Bermuda help evaluate hypotheses about the duration of the peak of the Last Interglacial period. The deep-sea oxygen isotope record, as discussed earlier, would suggest a peak Last Interglacial period, when global ice volume was similar to or less than present, of less than $3 \mathrm{ka}$ (based on the estimated time period from events 5.53 to 5.51 of Martinson et al., 1987). On the other hand, other records, such as Antarctic ice cores, Devils Hole calcite, Grand Pile pollen, and certain emergent reefs would indicate a much longer peak Last Interglacial duration (e.g, 10 ka estimated from Devils Hole; Winograd et al., 1997). The Oahu U-series data presented here have an age range of $\sim 134-113 \mathrm{ka}$, which is not significantly different from that reported by Szabo et al. (1994). McCulloch and Esat (2000) suggested that the Oahu data set of Szabo et al. (1994) was of too-low a precision to allow an estimate of the duration of the Last Interglacial period. However, our data set (different samples but from the same localities on Oahu) is of very high precision. We conclude that the concept of a long Last Interglacial period on Oahu, as proposed by Szabo et al. (1994) is still valid. Our new estimates indicate that peak Last-Interglacial conditions, when global ice volume was less than present, could have been many times longer than that estimated from the deep-sea oxygen isotope record.

Recent work on Lanai (Fig. 2) by Rubin et al. (2001) has yielded additional high-precision TIMS U-series ages of marine terrace corals. These deposits were originally considered to have been deposited by a giant wave generated by a submarine landslide (Moore and Moore, 1984, 1988), but are now interpreted to be marine terrace deposits that reached their present elevations by uplift (Rubin et al., 2001). If this interpretation is correct, then these U-series ages mark the time of relatively high sea levels during past interglacial events, including the Last Interglacial. Five corals analyzed by Rubin et al. (2001) have ages of $\sim 137-131$ ka with acceptable initial ${ }^{234} \mathrm{U} /{ }^{238} \mathrm{U}$ values. The Lanai coral ages overlap our oldest Oahu coral ages slightly but most are older (Fig. 11). It is important to note that the Lanai marine terrace deposits mostly have elevations that are higher than those on Oahu; one locality is at $3.8 \mathrm{~m}$, but the others range from 19 to $23 \mathrm{~m}$ above modern sea level (Rubin et al., 2001). Thus, although Oahu may be experiencing slow uplift (Muhs and Szabo, 1994), Lanai may be experiencing uplift rates that are higher. If Lanai is indeed experiencing uplift at a higher rate than Oahu, then somewhat older coral ages might be expected there.

Bradley and Griggs (1976) and Edwards et al. (1987) presented models of reef or terrace formation on uplifting coasts during the high-sea-level phase of an interglacial-glacial cycle. We have modified these models to incorporate the concepts of "keep-up," "catch-up" and "give-up" reef types, as outlined by Neumann and MacIntyre (1985). Lanai, with its higher uplift rate, should record an interglacial high sea stand sooner than Oahu as uplift keeps pace with rapidly rising sea level. The results from the present study seem to support this model. If so, then we might also expect to see similar differences on other coasts as well. To test this hypothesis, we compared the Bermuda U-series ages with those for Barbados. The difference in coral ages might be expected to be even greater than those for Oahu-Lanai, not only because Bermuda is tectonically stable compared to uplifting Barbados, but primarily because Bermuda patch reefs are "catch-up" types whereas Acropora palmata-dominated reefs on Barbados are "keep-up" types. A comparison with both the peak-Last Interglacial $(\sim 120 \mathrm{ka})$ corals (Devonshire member on Bermuda; Rendezvous Hill terrace on Barbados) and late-Last Interglacial ( $\sim 80 \mathrm{ka})$ corals (Southampton Formation on Bermuda and Worthing terrace on Barbados) supports the hypothesized lag of Bermudan coral growth (Fig. 12). Some of the analytical uncertainties for the Barbados corals are larger than what would be desirable for a rigorous test of the hypothesis; nevertheless, mass-spectrometric ${ }^{231} \mathrm{~Pa} /{ }^{235} \mathrm{U}$ dating of Barbados corals indicates that the ${ }^{230} \mathrm{Th} /{ }^{234} \mathrm{U}$ ages are probably valid (Edwards et al., 1997). Thus, we conclude that the sea-level model presented by Edwards et al. (1987) is supported by the comparison of U-series ages. If so, then the Last Interglacial high stand of sea recorded on the Hawaiian Islands may have begun around $\sim 135 \mathrm{ka}$ or even slightly before and remained high until at least $117 \mathrm{ka}$ or even slightly later. Sea level may have been high before $\sim 135 \mathrm{ka}$ because of a lag between the time of sea level rise and reef growth as observed by Hopley (1982, 1994) and Davies and Hopley (1983). We do not see any evidence in the array of U-series ages to infer a precipitous drop in sea level of $\sim 60-80 \mathrm{~m}$ at around $130 \mathrm{ka}$, as suggested in the studies of Esat et al. (1999) on New Guinea. We also do not see any persuasive evidence for two separate high stands of sea as interpreted by Sherman et al. (1993) from elsewhere on Oahu. However, the U-series data do support an interpretation that global warming with near-or-higher-than-present sea level could have occurred well before the northern high-latitude summer insolation peak of $\sim 126 \mathrm{ka}$. Such a hypothesis is also suggested by the Devils Hole, Nevada calcite record 
(Winograd et al., 1992, 1997) and the oxygen isotope record in Vostok, Antarctica ice cores (Lorius et al., 1985; Jouzel et al., 1993). The recent direct dating of marine sediments off the Bahamas islands by Henderson and Slowey (2000) also supports the concept of interglacial conditions occurring well before the northern high-latitude summer insolation peak at $\sim 126 \mathrm{ka}$.

\subsection{The dilemma of a high sea stand at $\sim 80 \mathrm{ka}$}

Although much more attention has been given to the $\sim 125 \mathrm{ka}$ high stand of sea, the magnitude of sea level rise at $\sim 80 \mathrm{ka}$ has also been actively debated, and careful studies show conflicting results. Indeed, on a global basis, there are about equal numbers of studies showing that this high stand was either relatively low or was relatively high. On Bermuda, as discussed earlier, a potential record of this high sea stand is the marine facies of the Southampton Formation found at Fort St. Catherine. Whereas Vacher and Hearty (1989) and Ludwig et al. (1996) interpreted this deposit to be indicative of an $\sim 80 \mathrm{ka}$ high sea stand close to the present, Harmon et al. (1983) and Toscano and Lundberg (1999) interpreted the marine sediments at Fort St. Catherine to be storm deposits. Because the deposits are not in situ patch reefs but bedded, poorly sorted, coral-bearing marine sands and gravels, a stormemplacement origin cannot be excluded. Based on the large suite of $\sim 80 \mathrm{ka}$ coral ages (and only $\sim 80 \mathrm{ka}$ coral ages), our interpretation is that the marine sediments at Fort St. Catherine do not represent a Holocene storm emplacement event, as hypothesized by Toscano and Lundberg (1999). It is possible that the deposits represent one or more storm emplacement events that occurred during the $\sim 80$ ka high sea stand, but the lack of $\sim 100 \mathrm{ka}$ corals, documented elsewhere on the Bermuda Platform northwest of Fort St. Catherine, may not support this interpretation.

Tectonically stable (or only slowly uplifting) coastlines around the world show conflicting records of sea level at $\sim 80 \mathrm{ka}$. On the tectonically stable east coast of the United States, a shallow submerged reef at Sand Cay off the Florida coast dated to $\sim 80 \mathrm{ka}$ has been interpreted both as indicating a sea level near present (Ludwig et al., 1996) or several meters below present (Toscano and Lundberg, 1999). On the tectonically stable Coastal Plain of the eastern United States, corals from emergent marine deposits a few meters above modern sea level (Savannah, Georgia; Charleston, South Carolina; Moyock, North Carolina; and Gomez, Virginia: see Fig. 3), have been dated at 75-80 ka using alpha-spectrometric ${ }^{230} \mathrm{Th} /{ }^{234} \mathrm{U}$ methods, supported by concordant ${ }^{231} \mathrm{~Pa} /{ }^{235} \mathrm{U}$ ages (Szabo, 1985). Redating of these corals using TIMS U-series methods has confirmed the 75-80 ka alpha-spectrometric ages (Wehmiller et al., 1997). The tectonically stable Bahamas show mixed evidence of sea level position at this time. U-series dating of submerged speleothems suggests that sea level was at least $10-15 \mathrm{~m}$ below present at $\sim 80 \mathrm{ka}$ (Lundberg and Ford, 1994; Richards et al., 1994). Conversely, ooids (which can form only when sea level is near present on the Bahamas platform) show evidence of a high sea stand younger than $\sim 120 \mathrm{ka}$, but not as young as Holocene (Hearty and Kaufman, 2000). The tectonically stable coast of Western Australia does not show any evidence of an $\sim 80 \mathrm{ka}$ high sea stand near present sea level (Stirling et al., 1995, 1998), nor does Isla de Guadalupe off the coast of Baja California (Muhs et al., 1994). On Oahu, a single U-series age of $\sim 80 \mathrm{ka}$ from a growth-position Porites lobata, at a depth of $\sim 30 \mathrm{~m}$, has been reported (Sherman et al., 1999). However, $P$. lobata can live from the intertidal zone to depths of $\sim 60 \mathrm{~m}$ below sea level (Maragos, 1977).

There are also conflicting estimates of paleo-sea level at $\sim 80 \mathrm{ka}$ from tectonically active coastlines. Terraces dated to $\sim 80 \mathrm{ka}$ on the tectonically rising islands of Barbados, Haiti and New Guinea (Mesolella et al., 1969; Bloom et al., 1974; Dodge et al., 1983) are estimated to have formed at a sea level $10-20 \mathrm{~m}$ below present, using the $120 \mathrm{ka}$ terrace to calculate an uplift rate and assuming linear tectonics over time. However, other tectonically rising coasts (Japan and California) suggest that sea level was slightly below, although close to present level at $\sim 80 \mathrm{ka}$, when calculated using the same methods (Ota and Omura, 1992; Muhs et al., 1994).

Despite the abundance of well-dated corals from both tectonically stable and rising coastlines and islands, we cannot come to any firm conclusions about paleo-sea level at $\sim 80 \mathrm{ka}$. One observation that can be made, however, is that those localities (Bermuda, eastern US Coastal Plain, California, Japan and perhaps the Bahamas) showing evidence of a near-present sea level at $\sim 80$ ka belong to what has been termed "intermediate-field" localities with respect to northern highlatitude ice sheets (Stirling et al., 1998). These localities are closer to limits of the penultimate Laurendtide ice sheet and are hypothesized to have experienced postglacial isostatic rebound that elevated $\sim 80$ and $\sim 105 \mathrm{ka}$ marine deposits to positions above modern sea level. In contrast, "far-field" coastlines (Australia, New Guinea and perhaps Barbados and Oahu), distant from northern high-latitude ice sheets, show no evidence of $\sim 80$ and $105 \mathrm{ka}$ marine deposits near present sea level. Nevertheless, an argument against the isostasy hypothesis is the observation that $\sim 125 \mathrm{ka}$ deposits on tectonically stable, intermediate-field localities (the Bahamas, Bermuda and localities in Baja California: see Harmon et al., 1983; Chen et al., 1991; Muhs et al., 1994) are not significantly higher than $\sim 125 \mathrm{ka}$ deposits on tectonically stable, far-field localities (Australia).

With regard to sea level at $\sim 80 \mathrm{ka}$, it is perhaps worth noting that summer insolation at $60^{\circ} \mathrm{N}$ was actually 
higher at $\sim 80 \mathrm{ka}$ than at $11 \mathrm{ka}$ (Berger and Loutre, 1991). At $65^{\circ} \mathrm{N}$, summer insolation at $\sim 80 \mathrm{ka}$ was only slightly below the $11 \mathrm{ka}$ maximum (Fig. 12). One of the most important centers of growth for the Laurentide ice sheet at these latitudes was Baffin Island, Canada. Recent studies of pollen and diatoms from widely separated lakes on Baffin Island show that climate at $\sim 80 \mathrm{ka}$ (estimated from concordant TL and IRSL ages) was warmer than at any time in the Holocene (Miller et al., 1999; Wolfe et al., 2000). One of the inferences from the Baffin Island studies is that under such conditions, there must have been essentially complete deglaciation of the Laurentide ice sheet at $\sim 80 \mathrm{ka}$ (Miller et al., 1999). If this conclusion is correct, then evidence of a high sea stand near present at $\sim 80 \mathrm{ka}$ should be expected.

\subsection{Paleozoogeography of North American coastal sites of Last-Interglacial age}

We compiled published, Last-Interglacial marine faunal data from around North America that can be compared to the faunas for Hawaii and Bermuda. In making this compilation, we used mostly mollusks, but also corals and ostracodes where such data were available. We limited our selection, as much as possible, to those localities with reliable U-series ages on corals. For those deposits lacking corals (mostly Greenland, Canada and Alaska) we consider as "Last Interglacial" those deposits that meet the following four criteria: (1) nonfinite radiocarbon ages, (2) a stratigraphic position that allows an inference of Last-Interglacial age (e.g., sediments directly overlain by dated Wisconsin-age deposits), (3) deposits that lie at elevations slightly above modern sea level in tectonically stable settings, and (4) amino acid ratios on mollusks that permit an interpretation of Last-Interglacial age. Some localities, such as those on Greenland, also have luminescence ages that support a Last-Interglacial age. Geographic ranges were updated from sources such as Keen (1971), Abbott (1974), Weisbord (1974), Kay (1979), Sterrer (1986), Abbott and Morris (1995), Coan et al. (2000), and web sites available at the Academy of Natural Sciences (Philadelphia), the Bernice P. Bishop Museum (Hawaii), and the Florida Museum of Natural History.

Results of this compilation show that high-latitude waters around North America and nearby islands had Last-Interglacial oceanic temperatures warmer than present (Fig. 13). Coastal waters around Alaska, in both the Arctic Ocean and the Bering Sea, show warmer-than-modern temperatures from both mollusks in Last Interglacial (Pelukian) marine terrace deposits and marine ostracodes collected from cores taken in Prudhoe Bay (McDougall et al., 1986; Brigham-Grette and Hopkins, 1995). For example, the bivalve Mya elegans (as Mya baxteri) has a modern northern range limit near Nome, Alaska $\left(\sim 64.5^{\circ} \mathrm{N}\right)$ on the Seward Peninsula (Coan et al., 2000), but is found in LastInterglacial marine deposits on the Arctic Coastal Plain of Alaska (Brigham-Grette and Hopkins, 1995), a northward range extension of more than $600 \mathrm{~km}$. Marine deposits from the Last Interglacial (Kogalu aminozone) of Baffin Island (Miller et al., 1992) contain subarctic faunas well north of their modern northern range endpoints (Miller et al., 1977; Nelson, 1981; Brigham, 1983). Two of the most common extralimital southern (subarctic) species of mollusks that have been reported in Last-Interglacial deposits are Chlamys islandica and Colus spitzbergensis, neither of which live in the colder, Arctic waters off eastern Baffin Island today. Mode (1985) also reported Astarte subaequilatera, which ranges today from Florida north only to Labrador (Abbott and Morris, 1995). Its presence in Last-Interglacial deposits of eastern Baffin Island indicates a northward range extension of as much as $1500 \mathrm{~km}$. Subarctic waters reached farther north than they do at present along the coasts of both West and East Greenland. In East Greenland, extralimital southern mollusks, such as C. islandica, today found only in subarctic waters, are present in emergent marine deposits of the Langelandselv interglaciation in the Jameson Land area (Funder et al., 1991, 1998; Hansen et al., 1994; Landvik et al., 1994; Tveranger et al., 1994). Luminescence age estimates suggest that these deposits date to the Last Interglacial period (Landvik et al., 1994; Mejdahl and Funder, 1994; Funder et al., 1998). In West Greenland, near Thule, warmer-than-present waters are also inferred for Last-Interglacial deposits, based on the presence of subarctic mollusks and barnacles that are at or north of their modern limits (Funder et al., 1991; Kelly et al., 1999).

Farther south along the Atlantic coast of Canada and into New England, warmer-than present waters are also inferred for the Last Interglacial period. Deposits in Nova Scotia have mollusks (Clarke et al., 1972) with amino acid ratios similar to those from coralbearing deposits with a Last-Interglacial age on Nantucket Island, Massachusetts, based on U-series dating (Oldale et al., 1982; Wehmiller et al., 1988). The Last-Interglacial deposits on Nova Scotia have a "neutral" fauna, without extralimital southern or northern species (Clarke et al., 1972). The same is true for the Last-Interglacial mollusks on Nantucket Island. However, the zoogeographic ranges of ostracodes in the marine deposits on Nantucket Island show a transition from warmer-than-modern conditions at the peak of the Last Interglacial period to coolerthan-modern conditions at the end of this period (Oldale et al., 1982).

Marine deposits from lower-latitude localities in Florida, the Bahamas, and the West Indies generally show "neutral" faunal thermal aspects (terminology of 


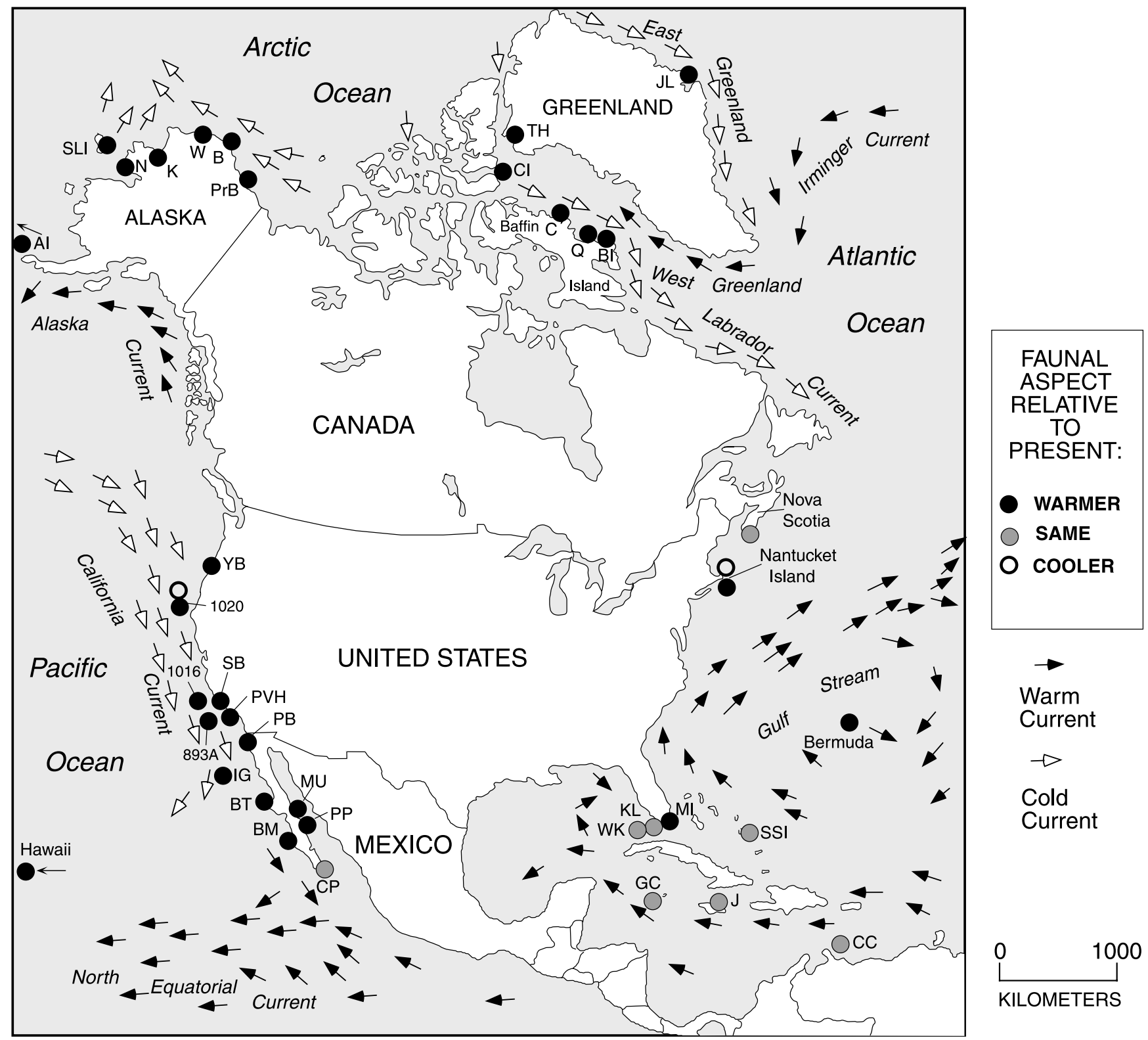

Fig. 13. Compilation of fossil localities that date (or probably date) to the peak of the last interglacial period around North America, their temperature aspects relative to modern waters based on presence or absence of extralimital southern or northern species in the fossil assemblages, and modern warm and cold ocean currents. Most localities shown are for mollusk data, but one has ostracodes (PrB), another has both mollusks and ostracodes (Nantucket Island), two others use mollusks and corals (Bermuda and Windley Key) and Ocean Drilling Program (ODP) sites off California use alkenone and foraminifera data. Correlation to the last interglacial period based on either U-series ages of corals (most localities in the continental United States and Mexico), amino acid ratios in mollusks (most localities in Canada and Alaska), amino acid ratios in mollusks and luminescence dating of sediments (localities in Greenland), or oxygen isotope stratigraphy (ODP sites off California). Abbreviations: PrB, Prudhoe Bay, Alaska; B, Barrow, Alaska; W, Wainwright, Alaska; K, Kotzebue, Alaska; SLI, St. Lawrence Island, Alaska; N, Nome, Alaska; AI, Amchitka Island, Alaska; YB, Yaquina Bay, Oregon; 1020, ODP Hole 1020, northern California; 1016, ODP Hole 1016, off Point Conception; SB, Santa Barbara, California; 893A, ODP Hole 893A, Santa Barbara Basin; PVH, Palos Verdes Hills, California; PB, Punta Banda, Baja California; IG, Isla de Guadalupe, Baja California; BT, Bahía Tortugas, Baja California Sur; BM, Bahía de Magdalena, Baja California Sur; CP, Cabo Pulmo, Baja California Sur; PP, Playa La Palmita, Baja California Sur; MU, Mulegé, Baja California Sur; CC, Curaçao; GC, Grand Cayman Island; J, Jamaica; WK, Windley Key, Florida; KL, Key Largo, Florida; MI, Miami, Florida; SSI, San Salvador Island, Bahamas; CI, Coburg Island, Canada; BI, Brougton Island, Canada; Q, Qivitu Peninsula, Canada; C, Clyde Foreland, Canada; TH, Thule area, Greenland; JL, Jameson Land, Greenland. Fossil and age data compiled by the authors from the following sources: Alaska: Allison (1973), Szabo and Gard (1975), McDougall et al. (1986), and Brigham-Grette and Hopkins (1995); Oregon and California: Kennedy (1978, 1992), Kennedy et al. (1982), Muhs et al. (1992, 1994), Kreitz et al. (2000); Yamamoto et al. (2000); Poore et al. (2000); Herbert et al. (1995); Woodring et al. (1946); Baja California: Rockwell et al. (1989), Omura et al. (1979), Libbey and Johnson (1997); Ortlieb (1984); Ashby et al. (1987); Emerson et al. (1981), and Squires (1959); Curacao: Buisonjé (1974), Schubert and Szabo (1978); Grand Cayman Island: Cerridwen and Jones (1991), Vézina et al. (1999); Jamaica: Szabo (1979), Donovan and Littlewood (1993); San Salvador Island: Hagey and Mylroie (1995) and Chen et al. (1991); Florida: Stanley (1966), Hoffmeister et al. (1967), Hoffmeister and Multer (1968), Halley and Evans (1983), and Fruijtier et al. (2000); Nantucket Island: Oldale et al. (1982); Nova Scotia: Clarke et al. (1972) and Wehmiller et al. (1988); Baffin Island and Coburg Island, Canada: Miller et al. (1977, 1992), Miller (1985), Mode (1985), Nelson (1981), and Brigham (1983); Greenland: Funder et al. (1991, 1998), Tveranger et al. (1994), Hansen et al. (1994), Landvik et al. (1994), Mejdahl and Funder (1994) and Kelly et al. (1999). 
Kennedy et al., 1982) in that they lack any extralimital species. On San Salvador Island in the Bahamas, the Cockburn Town reef has been well dated to the Last Interglacial period (Chen et al., 1991). The extensive molluscan fauna in this reef (Hagey and Mylroie, 1995) has species that all live in the region today. The same is true for molluscan faunas from lowelevation, emergent reefs on Curaçao, Grand Cayman Island, and Jamaica (Buisonjé, 1974; Cerridwen and Jones, 1991; Donovan and Littlewood, 1993), all of which have been dated to the Last Interglacial period (Schubert and Szabo, 1978; Szabo, 1979; Vézina et al., 1999). Thus, we interpret the faunas from the Caribbean to indicate water temperatures little different from those of today. In Florida, the Key Largo Limestone, dated to the Last Interglacial period (Fruijtier et al., 2000), also has a coral and mollusk fauna very similar to that found today in the Florida Keys, except for the absence of Acropora palmata (Stanley, 1966; Hoffmeister et al., 1967; Hoffmeister and Multer, 1968). However, in the Last-Interglacial Miami Limestone, an oolitic facies contemporary with the Key Largo Limestone, Halley and Evans (1983) report the gastropod Cittarium pica (also found in the Devonshire member of Bermuda) near Miami. Its presence in the Miami Limestone indicates that, during the Last Interglacial period, it was at least $150 \mathrm{~km}$ north of its northernmost, marginal modern range endpoint.

Oregon, California and Baja California have LastInterglacial faunas that mostly show warmer than present conditions in eastern Pacific waters, a conclusion reached by Kennedy et al. (1982) based on an earlier compilation. There are many localities that have either reliable Last-Interglacial U-series ages on coral (Omura et al., 1979; Rockwell et al., 1989; Muhs et al., 1994) or amino acid ratios in mollusks similar to those in nearby U-series-dated deposits (Kennedy et al., 1982, 1992; Muhs et al., 1992). These confidently dated deposits show warm-water signatures (Woodring et al., 1946; Valentine, 1961; Kennedy, 1978, 1992; Lindberg et al., 1980; Emerson et al., 1981; Kennedy et al., 1982; Ashby et al., 1987; Rockwell et al., 1989; Libbey and Johnson, 1997). Peak Last-Interglacial localities from the Gulf of California and along the Pacific coast from southern Baja California Sur to central Oregon have faunas with a distinctly southern, warm-water aspect.

In Baja California Sur, hermatypic colonial corals such as Porites and Pocillopora today range only as far north as La Paz in the Gulf of California (Johnson and Libbey, 1997) and Bahía Magdalena on the Pacific Coast (Squires, 1959). However, corals that date to the Last Interglacial period are known as far north as Isla de Guadalupe off the Pacific Coast (Lindberg et al., 1980) and Mulegé and Punta Chivato (Ashby et al., 1987; Libbey and Johnson, 1997) in the Gulf of California (Fig. 13). This indicates a Last-Interglacial, northward range extension of more than $300 \mathrm{~km}$ in the Gulf of California and more than $600 \mathrm{~km}$ on the Pacific Coast. Isla de Guadalupe's Last-Interglacial marine deposits also have at least ten extralimital southern species of mollusks (Lindberg et al., 1980). Six species from LastInterglacial deposits on Isla de Guadalupe, Purpura pausa, Thais planspira, Mitrella guttata, Mitra rupicola, Conus purpurascens, and Codakia distinguenda, presently live no farther north than southern Baja California Sur and range as far south as Panama, Colombia, Equador or Peru (Keen, 1971). This indicates Last-Interglacial northward range extensions of $600-800 \mathrm{~km}$. The Last Interglacial deposits on Isla de Guadalupe include at least one Indo-Pacific faunal element, the cowrie Cypraea cernica (Lindberg et al., 1980), which is known today at least as far east as Hawaii (Burgess, 1970; Kay, 1979), but is not otherwise known from the tropical eastern Pacific (Keen, 1971). If Hawaii is the closest modern record of $C$. cernica, its presence on Isla de Guadalupe represents a northeastern range extension of more than $4000 \mathrm{~km}$. In northern Baja California near Ensenada, the third emergent marine terrace at Punta Banda has confidently dated solitary corals of LastInterglacial age (Muhs et al., 1994). Extralimital southern mollusks such as the gastropods Macron aethiops and Stramonita biserialis in these deposits (Rockwell et al., 1989) do not range today any farther north than Isla Cedros in Baja California (Keen, 1971), indicating a northward range extension of more than $350 \mathrm{~km}$.

Farther north along the Pacific Coast of North America, there are numerous localities with emergent marine deposits or deep-sea sediments from cores that show warm-water signatures during the Last Interglacial period. Off the coast of California, alkenone data from the portions of Santa Barbara Basin ODP core 893A and Point Conception ODP core 1016 that date to oxygen isotope substage $5 \mathrm{e}$ indicate surface water temperatures as much as $4^{\circ} \mathrm{C}$ warmer than present (Herbert et al., 1995; Yamamoto et al., 2000). This higher-than-modern paleotemperature estimate is consistent with a warm-water molluscan fauna from a LastInterglacial marine terrace near Santa Barbara (Kennedy et al., 1992). Alkenone data from ODP core 1020 off northern California also indicate that sea surface temperatures were warmer than present during substage 5e (Yamamoto et al., 2000), which is consistent with a warm-water molluscan fauna from marine deposits on the coast of central Oregon (Kennedy, 1978; Kennedy et al., 1982). However, foraminifera data from ODP core 1020 indicate that offshore only the earliest part of substage 5e was warmer than present; cooler-than present temperatures off northern California are inferred for the latter part of this substage (Poore et al., 2000).

The picture that emerges from Hawaii, Bermuda, and the compilation of published data for localities around 
North America is that of a warmer-than-present Last Interglacial period. Northward movement of warmer waters likely played an important role in generating the faunas (Fig. 13). On Baffin Island, increased movement of warmer Atlantic water into the Labrador Sea and Baffin Bay might explain the warmer faunas there, as may also have been the case at $\sim 80 \mathrm{ka}$ (Miller et al., 1999). A stronger (warm) West Greenland Current could deliver relatively warmer Atlantic waters to both the northeastern coast of Baffin Island and the western coast of Greenland. Conversely, a weaker (cold) East Greenland Current could allow relatively warmer Atlantic waters to reach east Greenland. A stronger or warmer Gulf Stream may explain the warm faunas around Miami, on Bermuda, and perhaps Nantucket Island. On the west coast of North America, a weaker (cold) California Current with replacement by greater northward movement of warm, equatorial waters may explain the southern extralimital species in Baja California, California and Oregon. All modern corals in the Hawaiian Islands have their origins in the IndoWest Pacific region and the western boundary current system of the Pacific (Kuroshio and Subtropical Counter-Current) is the primary source for transport of coral larvae across the western part of the Pacific Ocean (Grigg, 1997). Thus, a stronger Kuroshio Current may also explain the presence of extralimital Indo-West Pacific mollusks around Oahu during the Last Interglacial period. Around Alaska, warmer waters from the North Pacific Ocean reached farther north and winter sea ice apparently did not extend south of Bering Strait during the Last Interglacial period (Brigham-Grette and Hopkins, 1995). In addition, the Last-Interglacial ostracode faunas from the Prudhoe Bay area indicate that more saline Atlantic water was present in that region and Arctic Ocean sea-ice cover must not have been perennial (Brigham-Grette and Hopkins, 1995).

The reconstruction of warmer-than-present LastInterglacial oceans around North America agrees with observations of Last-Interglacial conditions in other regions, such as Japan, the Mediterranean basin and Western Australia. Marine terrace deposits dated to the Last Interglacial period fringe much of the coastline of the Japanese Islands (Ota and Omura, 1991). On the Noto Peninsula of central Honshu, marine terrace deposits contain solitary corals that have been dated by $\mathrm{U}$-series methods to $115-125 \mathrm{ka}$, which corresponds to the peak of the Last Interglacial period (Omura, 1980). Last-Interglacial marine terrace deposits on the Noto Peninsula contain warm-water mollusks, including the subtropical species Apollon natator, Trisidos kiyonoi, and Dendostrea paulucciae (Matsuura, 1985). Matsuura (1985) interprets these to indicate that a warm current flowed into the Sea of Japan, including the embayment area of the Noto Peninsula, during the Last Interglacial period. Kitamura et al. (2000) have pointed out that a major source of heat for the Sea of Japan is the warm Tsushima Current, a branch of the Kuroshio Current, and that warm-water faunas characterize interglacial periods when this current has a strong presence in the Sea of Japan.

It has long been recognized that low-elevation marine deposits around the Mediterranean Sea, assigned to the "Tyrrhenian II" sea-level high stand, contain a distinctive warm-water "Senegalese" fauna and could date to the Last Interglacial period (Butzer and Cuerda, 1962). Corals from localities in Mallorca, Sardinia, southern Italy and Tunisia have now been dated to the peak of the Last Interglacial period at around $120-130 \mathrm{ka}$ by U-series methods (Hearty et al., 1986). Using amino acid ratios in mollusks, localities elsewhere in the region also have been correlated to this high stand of sea by the same workers. Many of the localities studied by Hearty et al. (1986) have the distinctive Senegalese molluscan fauna that contains the gastropods Strombus bubonius (as S. latus) and Conus testudinarius, and the bivalve Cardita senegalensis. These species presently live only off west Africa (Abbott and Dance, 2000). Thus, the presence of Senegalese mollusks in Mediterranean waters during the Last Interglacial period represents a northward range extension of over $2000 \mathrm{~km}$.

In Western Australia, deposits of Last-Interglacial age have been studied along almost the entire coastline (Kendrick et al., 1991; Collins et al., 1993; Zhu et al., 1993; Johnson et al., 1995; Stirling et al., 1995, 1998; McCulloch and Esat, 2000). McCulloch and Esat (2000), using $\mathrm{Sr} / \mathrm{Ca}$ values in the coral Porites, suggested that sea surface temperatures off Western Australia were not significantly different from modern values. Although reef-building corals presently live only as far south as $\sim 24^{\circ} \mathrm{S}$ (Veron, 1995), Johnson et al. (1995) report an emergent, Acropora-dominated reef of Last-Interglacial age as far south as $\sim 28.5^{\circ} \mathrm{S}$, a southward range extension of more than $500 \mathrm{~km}$ (Johnson and Libbey, 1997). Faunas from Last-Interglacial deposits of Western Australia also contain extralimital northern (i.e., warmer) mollusks (Kendrick et al., 1991). For example, Astralium rhodostomum is found in Last-Interglacial deposits that are $\sim 400 \mathrm{~km}$ south of its present southern range limit. Thus, although the "core" tropical region of Western Australia may not have warmed appreciably during the Last Interglacial period (on the basis of the $\mathrm{Sr} / \mathrm{Ca}$ values in corals), the subtropical region must have been considerably warmer than present.

\section{Conclusions}

New, higher-precision TIMS U-series ages of Waimanalo Formation corals from slowly uplifting Oahu, Hawaii range from $\sim 134$ to $\sim 113 \mathrm{ka}$, with most ages 
between $\sim 125$ and $\sim 115 \mathrm{ka}$. These ages are very similar to those reported earlier by Szabo et al. (1994). When combined with published U-series ages from nearby Lanai, which may be experiencing faster uplift, the data suggest a long Last Interglacial period that may have existed from $\sim 136$ to at least $115 \mathrm{ka}$. The results suggest that solar forcing may not have been the only control on ice sheet growth and decay, because summer insolation was at relatively low values at northern high latitudes at $\sim 136 \mathrm{ka}$ and at its lowest values of the past $200 \mathrm{ka}$ at $\sim 115 \mathrm{ka}$ (Berger and Loutre, 1991). Thus, the Oahu data continue to challenge the Milankovitch theory of climate change. On Bermuda, corals that date to the Last Interglacial period are derived from patch reefs that likely were "catch-up" responses to sea level rise. As a consequence, coral colonization may have occurred later on Bermuda ( 125-113 ka), but overlapped the time of coral growth on Oahu and Barbados. A logical next step in studies of the duration of the Last Interglacial period would be to date the Hawaiian and Bermuda corals using ${ }^{231} \mathrm{~Pa}$ (Edwards et al., 1997), as a further check on the reliability of the ages presented here.

A large number of emergent marine localities with faunal data on Hawaii, Bermuda and around North America have now been dated to the Last Interglacial period. Thus, it is possible to generate a compilation of faunal records from which Last-Interglacial ocean temperatures can be inferred. Both Oahu and Bermuda have a number of extralimital southern species of mollusks, suggesting warmer-than-present waters during the Last Interglacial period. Warmer waters are also suggested for Last-Interglacial localities around North America, including Alaska, Greenland, Baffin Island, Nantucket Island, southern Florida, Baja California, California, and Oregon. Studies in Japan, the Mediterranean Basin and Western Australia also show evidence of warmer-than-modern Last-Interglacial waters. Thus, it is likely that during the Last Interglacial period, there was a greater movement of warm waters to higher latitudes than is the case today.

\section{Acknowledgements}

This study was supported by the Earth Surface Dynamics Program of the US Geological Survey and is a contribution to the LITE (Last Interglacial: Timing and Environment) Project. Muhs' field work on Oahu was funded by the US Geological Survey Earth Surface Dynamics Program; that on Bermuda was supported jointly by this program and the National Geographic Society. We appreciate stimulating discussions of Bermuda geology with Len Vacher (University of South Florida). Gene Shinn (US Geological Survey) identified the corals from Grape Bay, Bermuda; John Reed
(Harbor Branch Oceanographic Institution) identified the corals from Fort St. Catherine, Bermuda; and John Pandolfi (Smithsonian Institution) and George Kennedy (San Diego State University) identified the corals from Oahu. Lindsey Groves (Natural History Museum of Los Angeles County) and George Kennedy kindly provided some of specimens from Grape Bay that had been collected by Heinz Lowenstam (California Institute of Technology) in the 1950s. We also appreciate very helpful discussions with Lindsey Groves on Indo-Pacific molluscan zoogeography. Akihisa Kitamura (Shizuoka University) provided useful references on Last-Interglacial mollusks in Japan. George Kennedy, Larry Edwards (University of Minnesota), Chip Fletcher (University of Hawaii), Len Vacher and Ike Winograd (US Geological Survey) provided helpful comments on an earlier draft of the paper.

\section{References}

Abbot, R.T., 1960. The genus Strombus in the Indo-Pacific. IndoPacific Mollusca 1, 33-144.

Abbot, R.T., 1961. The genus Lambis in the Indo-Pacific. Indo-Pacific Mollusca 1, 147-174.

Abbott, R.T., 1974. American Seashells, 2nd Edition. Van Nostrand Reinhold Company, New York, 663 pp.

Abbott, R.T., Dance, S.P., 2000. Compendium of Seashells. Odyssey Publishing, El Cajon, California, 411 pp.

Abbott, R.T., Morris, P.A., 1995. A Field Guide to Shells of the Atlantic and Gulf coasts and the West Indies, 4th Edition. Houghton Mifflin Company, Boston, 350 pp.

Allison, R.C., 1973. Marine paleoclimatology and paleoecology of a Pleistocene invertebrate fauna from Amchitka Island, Aleutian Islands, Alaska. Palaeogeography, Palaeoclimatology, Palaeoecology $13,15-48$.

Ashby, J.R., Ku, T.-L., Minch, J.A., 1987. Uranium series ages of corals from the upper Pleistocene Mulegé terrace Baja California Sur Mexico. Geology 15, 139-141.

Bard, E., Hamelin, B., Fairbanks, R.G., 1990. U-Th ages obtained by mass spectrometry in corals from Barbados: sea level during the past 130,000 years. Nature 346, 456-458.

Berger, A., Loutre, M.F., 1991. Insolation values for the climate of the last 10 million years. Quaternary Science Reviews 10, 297-317.

Bernard, F.R., Cai, Y.-Y., Morton, B., 1993. Catalogue of the Living Marine Bivalve Molluscs of China. Hong Kong University Press, Hong Kong, 146 pp.

Bloom, A.L., Broecker, W.S., Chappell, J.M.A., Matthews, R.K., Mesolella, K.J., 1974. Quaternary sea level fluctuations on a tectonic coast: new ${ }^{230} \mathrm{Th} /{ }^{234} \mathrm{U}$ dates from the Huon Peninsula, New Guinea. Quaternary Research 4, 185-205.

Bradley, W.C., Griggs, G.B., 1976. Form, genesis, and deformation of central California wave-cut platforms. Geological Society of America Bulletin 87, 433-449.

Brigham, J.K., 1983. Stratigraphy, amino acid geochronology, and correlation of Quaternary sea-level and glacial events, Broughton Island, arctic Canada. Canadian Journal of Earth Sciences 20, 577-598.

Brigham-Grette, J., Hopkins, D.M., 1995. Emergent marine record and paleoclimate of the last interglaciation along the northwest Alaskan coast. Quaternary Research 43, 159-173. 
Broecker, W.S., 1998. The end of the present interglacial: how and when? Quaternary Science Reviews 17, 689-694.

Buddemeier, R.W., Smith, S.V., 1988. Coral reef growth in an era of rapidly rising sea-level. Coral Reefs 7, 51-56.

Buisonjé, P.H. De, 1974. Neogene and Quaternary geology of Aruba, Curaçao and Bonaire (Netherlands Antilles). Uitgaven van de Stichting Natuurwetenschappelijke Studiekring voor Suriname en de Nederlandse Antillen, 78, 293 pp.

Burgess, C.M., 1970. The Living Cowries. A.S. Barnes and Company, New York.

Butzer, K.W., Cuerda, J., 1962. Coastal stratigraphy of southern Mallorca and its implications for the Pleistocene chronology of the Mediterranean Sea. Journal of Geology 70, 398-416.

Cabioch, G., Montaggioni, L.F., Faure, G., Ribaud-Laurenti, A., 1999. Reef coralgal assemblages as recorders of paleobathymetry and sea level changes in the Indo-Pacific province. Quaternary Science Reviews 18, 1681-1695.

Cernohorsky, W.O., 1976. The Mitridae of the world. Part I. The subfamily Mitrinae. Indo-Pacific Mollusca 3, 273-528.

Cernohorsky, W.O., 1978. Tropical Pacific Marine Shells. Pacific Publications, Sydney, 352 pp.

Cerridwen, S.A., Jones, B., 1991. Distribution of bivalves and gastropods in the Pleistocene Ironshore Formation, Grand Cayman, British West Indies. Caribbean Journal of Science 27, 97-116.

Chen, J.H., Edwards, R.L., Wasserburg, G.J., $1986 .{ }^{238} \mathrm{U},{ }^{234} \mathrm{U}$, and ${ }^{232} \mathrm{Th}$ in seawater. Earth and Planetary Science Letters 80, 241-251.

Chen, J.H., Curran, H.A., White, B., Wasserburg, G.J., 1991. Precise chronology of the last interglacial period: ${ }^{234} \mathrm{U}-{ }^{230} \mathrm{Th}$ data from fossil coral reefs in the Bahamas. Geological Society of America Bulletin 103, 82-97.

Cheng, H., Edwards, R.L., Hoff, J., Gallup, C.D., Richards, D.A., Asmerom, Y., 2000. The half-lives of uranium-234 and thorium230. Chemical Geology 169, 17-33.

Chiappone, M., Sullivan, K.M., Lott, C., 1996. Hermatypic scleractinian corals of the southeastern Bahamas: a comparison to western Atlantic reef systems. Caribbean Journal of Science $32,1-13$.

Clague, D.A., Dalrymple, G.B., 1987. The Hawaiian-Emperor volcanic chain Part I: geologic evolution. US Geological Survey Professional Paper 1350, 5-54.

Clarke, A.H., Grant, D.R., MacPherson, E., 1972. The relationship of Actractodon stonei (Pilsbry) (Mollusca, Buccinidae) to Pleistocene stratigraphy and paleoecology of southwestern Nova Scotia. Canadian Journal of Earth Sciences 9, 1030-1038.

CLIMAP Project Members, 1984. The last interglacial ocean. Quaternary Research 21, 123-224.

Coan, E.V., Scott, P.V., Bernard, F.R., 2000. Bivalve seashells of western North America: Marine bivalve mollusks from Arctic Alaska to Baja California. Santa Barbara, Santa Barbara Museum of Natural History Monographs 2, 764.

Collins, L.B., Zhu, Z.R., Wyrwoll, K.-H., Hatcher, B.G., Playford, P.E., Chen, J.H., Eisenhauer, A., Wasserburg, G.J., 1993. Late Quaternary evolution of coral reefs on a cool-water carbonate margin: the Abrolhos carbonate platforms, southwest Australia. Marine Geology 110, 203-212.

Cortijo, E., Lehman, S., Keigwin, L., Chapman, M., Paillard, D., Labeyrie, L., 1999. Changes in meridional temperature and salinity gradients in the North Atlantic Ocean $\left(30^{\circ}-72^{\circ} \mathrm{N}\right)$ during the last interglacial period. Paleoceanography 14, 23-33.

Davies, P.J., Hopley, D., 1983. Growth facies and growth rates of Holocene reefs in the Great Barrier Reef. BMR Journal of Australian Geology and Geophysics 8, 237-251.

Dodge, R.E., Fairbanks, R.G., Benninger, L.K., Maurrasse, F., 1983. Pleistocene sea levels from raised coral reefs of Haiti. Science 219, $1423-1425$.
Donovan, S.K., Littlewood, D.T.J., 1993. The benthic mollusk faunas of two contrasting reef paleoenvironments: Falmouth formation (late Pleistocene, last interglacial), Jamaica. The Nautilus 107, 33-42.

Easton, W.H., Ku, T.L., 1981. ${ }^{230} \mathrm{Th} /{ }^{234} \mathrm{U}$ dates of Pleistocene deposits on Oahu. Bulletin of Marine Science 31, 552-557.

Easton, W.H., Olson, E.A., 1976. Radiocarbon profile of Hanauma Reef, Oahu, Hawaii. Geological Society of America Bulletin 87, 711-719.

Edwards, R.L., Chen, J.H., Ku, T.-L., Wasserburg, G.J., 1987. Precise timing of the last interglacial period from mass spectrometric determination of thorium-230 in corals. Science 236, $1547-1553$.

Edwards, R.L., Cheng, H., Murrell, M.T., Goldstein, S.J., 1997. Protactinium-231 dating of carbonates by thermal ionization mass spectrometry: implications for Quaternary climate change. Science 276, 782-786.

Emerson, W.K., Kennedy, G.L., Wehmiller, J.F., Keenan, E., 1981. Age relations and zoogeographic implications of late Pleistocene marine invertebrate faunas from Turtle Bay, Baja California Sur, Mexico. The Nautilus 95, 105-116.

Epstein, S., Lowenstam, H.A., 1953. Temperature-shell-growth relations of recent and interglacial Pleistocene shoal-water biota from Bermuda. Journal of Geology 61, 424-438.

Esat, T.M., McCulloch, M.T., Chappell, J., Pillans, B., Omura, A., 1999. Rapid fluctuations in sea level recorded at Huon Peninsula during the penultimate deglaciation. Science 283, 197-201.

Fairbanks, R.G., 1989. A 17,000-year glacio-eustatic sea level record: influence of glacial melting rates on the Younger Dryas event and deep-ocean circulation. Nature 342, 637-642.

Fruijtier, C., Elliott, T., Schlager, W., 2000. Mass-spectrometric ${ }^{234} \mathrm{U}^{2}{ }^{230} \mathrm{Th}$ ages from the Key Largo Formation, Florida Keys, United States: constraints on diagenetic age disturbance. Geological Society of America Bulletin 112, 267-277.

Funder, S., Hjort, C., Kelly, M., 1991. Isotope stage 5 (130-74 ka) in Greenland, a review. Quaternary International 10-12, 107-122.

Funder, S., Hjort, C., Landvik, J.Y., Nam, S.-I., Reeh, N., Stein, R., 1998. History of a stable ice margin-East Greenland during the middle and upper Pleistocene. Quaternary Science Reviews 17, 77-123.

Gallup, C.D., Edwards, R.L., Johnson, R.G., 1994. The timing of high sea levels over the past 200,000 years. Science 263, 796-800.

Garrett, P., Smith, D.L., Wilson, A., Patriquin, D., 1971. Physiography, ecology, and sediments of two Bermuda patch reefs. Journal of Geology 79, 647-668.

Grigg, R.W., 1997. Paleoceanography of coral reefs in the HawaiianEmperor Chain-Revisited. Coral Reefs 16 (Suppl.), 33-38.

Hagey, F.M., Mylroie, J.E., 1995. Pleistocene lake and lagoon deposits, San Salvador Island, Bahamas. Geological Society of America Special Paper 300, 77-90.

Halley, R.B., Evans, C.C., 1983. The Miami Limestone: A Guide to Selected Outcrops and their Interpretation. Miami Geological Society, Miami, 67 pp.

Hamelin, B., Bard, E., Zindler, A., Fairbanks, R.G., 1991. ${ }^{234} \mathrm{U} /{ }^{238} \mathrm{U}$ mass spectrometry of corals: how accurate is the U-Th age of the last interglacial period? Earth and Planetary Science Letters 106, $169-180$.

Hansen, L.A., Jorgensen, M.E., Houmark-Nielsen, M., Kronborg, C., 1994. Late Pleistocene stratigraphy and depositional environments of the Fynselv area, Jameson Land, East Greenland. Boreas 23, 385-397.

Harmon, R.S., Schwarcz, H.P., Ford, D.C., 1978. Late Pleistocene sea level history of Bermuda. Quaternary Research 9, 205-218.

Harmon, R.S., Mitterer, R.M., Kriausakul, N., Land, L.S., Schwarcz, H.P., Garrett, P., Larson, G.J., Vacher, H.L., Rowe, M., 1983. $\mathrm{U}$-series and amino-acid racemization geochronology of Bermuda: 
implications for eustatic sea-level fluctuation over the past 250,000 years. Palaeogeography, Palaeoclimatology, Palaeoecology 44, 41-70.

Hearty, P.J., Kaufman, D.S., 2000. Whole-rock aminostratigraphy and Quaternary sea-level history of the Bahamas. Quaternary Research 54, 163-173.

Hearty, P.J., Kindler, P., 1995. Sea-level highstand chronology from stable carbonate platforms (Bermuda and the Bahamas). Journal of Coastal Research 11, 675-689.

Hearty, P.J., Miller, G.H., Stearns, C.E., Szabo, B.J., 1986. Aminostratigraphy of Quaternary shorelines in the Mediterranean basin. Geological Society of America Bulletin 97, 850-858.

Hearty, P.J., Vacher, H.L., Mitterer, R.M., 1992. Aminostratigraphy and ages of Pleistocene limestones of Bermuda. Geological Society of America Bulletin 104, 471-480.

Henderson, G.M., Slowey, N.C., 2000. Evidence from U-Th dating against Northern Hemisphere forcing of the penultimate deglaciation. Nature 404, 61-66.

Herbert, T.D., Yasuda, M., Burnett, C., 1995. Glacial-interglacial seasurface temperature record inferred from alkenone unsaturation indices, site 893, Santa Barbara Basin. Proceedings of the Ocean Drilling Program, Scientific Results 146 (pt. 2), 257-264.

Herwitz, S.R., Muhs, D.R., 1995. Bermuda solution pipe soils: a geochemical evaluation of eolian parent materials. Geological Society of America Special Paper 300, 311-323.

Hoffmeister, J.E., Multer, H.G., 1968. Geology and origin of the Florida Keys. Geological Society of America Bulletin 79, $1487-1502$.

Hoffmeister, J.E., Stockman, K.W., Multer, H.G., 1967. Miami Limestone of Florida and its recent Bahamian counterpart. Geological Society of America Bulletin 78, 175-190.

Hopley, D., 1982. The Geomorphology of the Great Barrier Reef: Quaternary Development of Coral Reefs. John Wiley and Sons, New York, 453 pp.

Hopley, D., 1994. Continental shelf reef systems. In: Carter, R.W.G., Woodroffe, C.D. (Eds.), Coastal Evolution: Late Quaternary Shoreline Morphodynamics. Cambridge University Press, Cambridge, pp. 303-340.

Johnson, M.E., Libbey, L.K., 1997. Global review of upper Pleistocene (substage 5e) rocky shores: tectonic segregation, substrate variation, and biological diversity. Journal of Coastal Research 13, 297-307.

Johnson, M.E., Baarli, B.G., Scott Jr., J.H., 1995. Colonization and reef growth on a late Pleistocene rocky shore and abrasion platform in Western Australia. Lethaia 28, 85-98.

Jouzel, J., Barkov, N.I., Barnola, J.M., Bender, M., Chappellaz, J., Genthon, C., Kotlyakov, V.M., Lipenkov, V., Lorius, C., Petit, J.R., Raynaud, D., Raisbeck, G., Ritz, C., Sowers, T., Stievenard, M., Yiou, F., Yiou, P., 1993. Extending the Vostok ice-core record of paleoclimate to the penultimate glacial period. Nature 364, 407-412.

Kay, E.A., 1979. Hawaiian marine shells. Bernice P. Bishop Museum Special Publication, Vol. 64(4). Bishop Museum Press, Honolulu, Hawaii, 653 pp.

Keen, A.M., 1971. Sea Shells of Tropical West America, 2nd Edition. Stanford University Press, Stanford, California, 1064 pp.

Kelly, M., Funder, S., Houmark-Nielsen, M., Knudsen, K.L., Kronborg, C., Landvik, J., Sorby, L., 1999. Quaternary glacial and marine environmental history of northwest Greenland: a review and reappraisal. Quaternary Science Reviews 18, 373-392.

Kendrick, G.W., Wyrwoll, K.-H., Szabo, B.J., 1991. PliocenePleistocene coastal events and history along the western margin of Australia. Quaternary Science Reviews 10, 419-439.

Kennedy, G.L., 1978. Pleistocene paleoecology, zoogeography and geochronology of marine invertebrate faunas of the Pacific
Northwest coast (San Francisco Bay to Puget Sound). Unpublished $\mathrm{Ph} . D$. dissertation, University of California-Davis, $824 \mathrm{pp}$.

Kennedy, G.L., 2000. Zoogeographic correlation of marine invertebrate faunas. In: Noller, J.S., Sowers, J.M., Lettis, W.R. (Eds.), Quaternary Geochronology: Methods and Applications. American Geophysical Union Reference Shelf 4. American Geophysical Union, Washington, DC, pp. 413-424.

Kennedy, G.L., Lajoie, K.R., Wehmiller, J.F., 1982. Aminostratigraphy and faunal correlations of late Quaternary marine terraces, Pacific Coast, USA. Nature 299, 545-547.

Kilburn, R.N., 1983. The Recent Arcidae (Mollusca: Bivalvia) of Southern Africa and Mozambique. Annals of the Natal Museum $25,511-548$.

Kitamura, A., Omote, H., Oda, M., 2000. Molluscan response to early Pleistocene rapid warming in the Sea of Japan. Geology 28, 723-726.

Kohn, A.J., 1980. Conus kahiko, a new Pleistocene gastropod from Oahu, Hawaii. Journal of Paleontology 54, 534-541.

Kosuge, S., 1969. Fossil mollusks of Oahu, Hawaii Islands. Bulletin of the National Science Museum [Tokyo, Japan] 12, 783-794.

Kreipl, K., Poppe, G.T., 1999. The Family Strombidae. A Conchological Iconography. Conch Books, Hackenheim, Germany, $59 \mathrm{pp}$.

Ku, T.-L., Kimmel, M.A., Easton, W.H., O’Neil, T.J., 1974. Eustatic sea level 120,000 years ago on Oahu, Hawaii. Science 183, 959-962.

Kukla, G., McManus, J.F., Rousseau, D.-D., Chuine, I., 1997. How long and how stable was the last interglacial? Quaternary Science Reviews 16, 605-612.

Landvik, J.Y., Lyså, A., Funder, S., Kelly, M., 1994. The Eemian and Weichselian stratigraphy of the Langelandselv area, Jameson Land, East Greenland. Boreas 23, 412-423.

Libbey, L.K., Johnson, M.E., 1997. Upper Pleistocene rocky shores and intertidal biotas at Playa La Palmita (Baja California Sur, Mexico). Journal of Coastal Research 13, 216-225.

Lindberg, D.R., Roth, B., Kellog, M.G., Hubbs, C.L., 1980. Invertebrate megafossils of Pleistocene (Sangamon interglacial) age from Isla de Guadalupe, Baja California, Mexico. In: Power, D.M. (Ed.), The California Islands: Proceedings of a Multidisciplinary Symposium. Santa Barbara Museum of Natural History, Santa Barbara, pp. 41-70.

Lorius, C., Jouzel, J., Ritz, C., Merlivat, L., Barkov, N.I., Korotkevich, Y.S., Kotlyakov, V.M., 1985. A 150,000-year climatic record from Antarctic ice. Nature 316, 591-596.

Ludwig, K.R., Szabo, B.J., Moore, J.G., Simmons, K.R., 1991. Crustal subsidence rate off Hawaii determined by ${ }^{234} \mathrm{U} /{ }^{238} \mathrm{U}$ ages of drowned coral reefs. Geology 19, 171-174.

Ludwig, K.R., Simmons, K.R., Szabo, B.J., Winograd, I.J., Landwehr, J.M., Riggs, A.C., Hoffman, R.J., 1992. Mass-spectrometric ${ }^{230} \mathrm{Th}-{ }^{234} \mathrm{U}-{ }^{238} \mathrm{U}$ dating of the Devils Hole calcite vein. Science 258, 284-287.

Ludwig, K.R., Muhs, D.R., Simmons, K.R., Halley, R.B., Shinn, E.A., 1996. Sea level records at $\sim 80 \mathrm{ka}$ from tectonically stable platforms: Florida and Bermuda. Geology 24, 211-214.

Lum, D., Stearns, H.T., 1970. Pleistocene stratigraphy and eustatic history based on cores at Waimanalo, Oahu, Hawaii. Geological Society of America Bulletin 81, 1-16.

Lundberg, J., Ford, D.C., 1994. Late Pleistocene sea level change in the Bahamas from mass spectrometric U-series dating of submerged speleothem. Quaternary Science Reviews 13, 1-14.

MacIntyre, I.G., 1988. Modern coral reefs of western Atlantic: new geological perspective. The American Association of Petroleum Geologists Bulletin 72, 1360-1369.

Maragos, J.E., 1977. Order Scleractinia: stony corals. In: Devaney, D.M., Eldredge, L.G. (Eds.), Reef and shore fauna of Hawaii. Bernice P. Bishop Museum Special Publication, Vol. 64 (1). Bishop Museum Press, Honolulu, Hawaii, pp. 158-241. 
Martinson, D.G., Pisias, N.G., Hays, J.D., Imbrie, J., Moore Jr., T.C., Shackleton, N.J., 1987. Age dating and the orbital theory of the ice ages: development of a high-resolution 0 to 300,000-year chronostratigraphy. Quaternary Research 27, 1-29.

Matsuura, N., 1985. Successive changes of the marine molluscan faunas from Pliocene to Holocene in Hokuriku region, central Japan. Bulletin of the Mizunami Fossil Museum 12, 71-158.

McCulloch, M.T., Esat, T., 2000. The coral record of last interglacial sea levels and sea surface temperatures. Chemical Geology 169, 107-129.

McDougall, K., Brouwers, E., Smith, P., 1986. Micropaleontology and sedimentology of the PB borehole series, Prudhoe Bay, Alaska. US Geological Survey Bulletin 1598, 1-62.

McManus, J.F., Bond, G.C., Broecker, W.S., Johnsen, S., Labeyrie, L., Higgins, S., 1994. High-resolution climate records from the North Atlantic during the last interglacial. Nature 371, 326-329.

Meischner, D., Vollbrecht, R., Wehmeyer, D., 1995. Pleistocene sealevel yo-yo recorded in stacked beaches, Bermuda south shore. Geological Society of America Special Paper 300, 295-310.

Mejdahl, V., Funder, S., 1994. Luminescence dating of late Quaternary sediments from East Greenland. Boreas 23, 525-535.

Mesolella, K.J., Matthews, R.K., Broecker, W.S., Thurber, D.L., 1969. The astronomical theory of climatic change: Barbados data. Journal of Geology 77, 250-274.

Miller, G.H., 1985. Aminostratigraphy of Baffin Island shell-bearing deposits. In: Andrews, J.T. (Ed.), Quaternary Environments: Eastern Canadian Arctic, Baffin Bay and Western Greenland. Allen and Unwin, Boston, pp. 394-427.

Miller, G.H., Andrews, J.T., Short, S.K., 1977. The last interglacialglacial cycle, Clyde Foreland, Baffin Island, N.W.T: stratigraphy, biostratigraphy, and chronology. Canadian Journal of Earth Sciences 14, 2824-2857.

Miller, G.H., Funder, S., de Vernal, A., Andrews, J.T., 1992. Timing and character of the last interglacial-glacial transition in the eastern Canadian Arctic and northwest Greenland. Geological Society of America Special Paper 270, 223-231.

Miller, G.H., Mode, W.N., Wolfe, A.P., Sauer, P.E., Bennike, O., Forman, S.L., Short, S.K., Stafford Jr., T.W., 1999. Stratified interglacial lacustrine sediments from Baffin Island, Arctic Canada: chronology and paleoenvironmental implications. Quaternary Science Reviews 18, 789-810.

Mode, W.N., 1985. Pre-Holocene pollen and molluscan records from eastern Baffin Island. In: Andrews, J.T. (Ed.), Quaternary environments: Eastern Canadian Arctic, Baffin Bay and Western Greenland. Allen and Unwin, Boston, pp. 502-519.

Montoya, M., Crowley, T.J., von Storch, H., 1998. Temperatures at the last interglacial simulated by a coupled ocean-atmosphere climate model. Paleoceanography 13, 170-177.

Moore, G.W., Moore, J.G., 1988. Large-scale bedforms in boulder gravel produced by giant waves in Hawaii. Geological Society of America Special Paper 229, 101-110.

Moore, J.G., 1987. Subsidence of the Hawaiian Ridge. US Geological Survey Professional Paper 1350, 85-100.

Moore, J.G., Moore, G.W., 1984. Deposit from a giant wave on the island of Lana'i, Hawaii. Science 226, 1312-1315.

Muhs, D.R., Szabo, B.J., 1994. New uranium-series ages of the Waimanalo Limestone, Oahu, Hawaii: implications for sea level during the last interglacial period. Marine Geology 118, 315-326.

Muhs, D.R., Kennedy, G.L., Rockwell, T.K., 1994. Uranium-series ages of marine terrace corals from the Pacific coast of North America and implications for last-interglacial sea level history. Quaternary Research 42, 72-87.

Muhs, D.R., Miller, G.H., Whelan, J.F., Kennedy, G.L., 1992. Aminostratigraphy and oxygen isotope stratigraphy of marine terrace deposits, Palos Verdes Hills and San Pedro areas, Los
Angeles County, California. In: Wehmiller, J.F., Fletcher III, C.H., (Eds.), Quaternary Coasts of the United States: Marine and Lacustrine Systems. Society of Economic Paleontologists and Mineralogists Special Publication, Vol. 48, pp. 363-376.

Nelson, A.R., 1981. Quaternary glacial and marine stratigraphy of the Qivitu Peninsula, northern Cumberland Peninsula, Baffin Island, Canada: summary. Geological Society of America Bulletin, Part I 92, 512-518.

Neumann, A.C., MacIntyre, I., 1985. Reef response to sea level rise: keep-up, catch-up or give-up. Proceedings of the Fifth International Coral Reef Congress 3, 105-110.

Oldale, R.N., Valentine, P.C., Cronin, T.M., Spiker, E.C., Blackwelder, B.W., Belknap, D.F., Wehmiller, J.F., Szabo, B.J., 1982. Stratigraphy, structure, absolute age, and paleontology of the upper Pleistocene deposits at Sankaty Head, Nantucket Island, Massachusetts. Geology 10, 246-252.

Omura, A., 1980. Uranium-series age of the Hiradoko and Uji shell beds, Noto Peninsula, central Japan. Transactions and Proceedings of the Palaeontological Society of Japan, New Series 117, 247-253.

Omura, A., Emerson, W.K., Ku, T.L., 1979. Uranium-series ages of echinoids and corals from the upper Pleistocene Magdalena terrace, Baja California Sur, Mexico. The Nautilus 94, 184-189.

Ortlieb, L., 1984. Field-Trip Guidebook: Neotectonics and Sea Level Variations in the Gulf of California Area. Instituto de Geología Universidad Nacíonal Autonoma de México, $152 \mathrm{pp}$.

Ostergaard, J.M., 1928. Fossil marine mollusks of Oahu. Bernice P. Bishop Museum Bulletin 51, 5-32.

Ota, Y., Omura, A., 1991. Late Quaternary shorelines in the Japanese Islands. Daiyonki-Kenkyu $=$ The Quaternary Research 30 , $175-186$.

Ota, Y., Omura, A., 1992. Contrasting styles and rates of tectonic uplift of coral reef terraces in the Ryukyu and Daito Islands, southwestern Japan. Quaternary International 15/16, 17-29.

Poore, R.Z., Dowsett, H.J., Barron, J.A., Heusser, L., Ravelo, A.C., Mix., A., 2000. Multiproxy record of the last interglacial (MIS 5e) off central and northern California, USA, from Ocean Drilling Program Sites 1018 and 1020. US Geological Survey Professional Paper 1632, 19 pp.

Richards, D.A., Smart, P.L., Edwards, R.L., 1994. Maximum sea levels for the last glacial period from U-series ages of submerged speleothems. Nature 367, 357-360.

Richards, H.G., Abbott, R.T., Skymer, T., 1969. The marine Pleistocene mollusks of Bermuda. Notulae Naturae 425, 1-10.

Rockwell, T.K., Muhs, D.R., Kennedy, G.L., Hatch, M.E., Wilson, S.H., Klinger, R.E., 1989. Uranium-series ages, faunal correlations and tectonic deformation of marine terraces within the Agua Blanca fault zone at Punta Banda, northern Baja California, Mexico. In: Abbott, P.L. (Ed.), Geologic Studies in Baja California. Los Angeles, Pacific Section, Society of Economic Paleontologists and Mineralogists Book 63, pp. 1-16.

Rubin, K.H., Fletcher III, C.H., Sherman, C., 2001. Fossiliferous Lana'i deposits formed by multiple events rather than a single giant tsunami. Nature 408, 675-681.

Schubert, C., Szabo, B.J., 1978. Uranium-series ages of Pleistocene marine deposits on the islands of Curaçao and La Blanquilla, Caribbean Sea. Geologie en Mijnbouw 57, 325-332.

Sherman, C.E., Fletcher III, C.H., Rubin, K.H., 1999. Marine and meteoric diagenesis of Pleistocene carbonates from a nearshore submarine terrace, Oahu, Hawaii. Journal of Sedimentary Research 69, 1083-1097.

Sherman, C.E., Glen, C.R., Jones, A.T., Burnett, W.C., Schwarcz, H.P., 1993. New evidence for two highstands of the sea during the last interglacial, oxygen isotope substage 5e. Geology 21, 1079-1082. 
Shinn, E.A., Lidz, B.H., Kindinger, J.L., Hudson, J.H., Halley, R.B., 1989. Reefs of Florida and the Dry Tortugas: A Guide to the Modern Carbonate Environments of the Florida Keys and the Dry Tortugas. US Geological Survey, St. Petersburg, Florida, 53 pp.

Squires, D.F., 1959. Results of the Puritan-American Museum of Natural History expedition to western Mexico. 7. Corals and coral reefs in the Gulf of California. Bulletin of the American Museum of Natural History 118, 367-432.

Stanley, S.M., 1966. Paleoecology and diagenesis of Key Largo Limestone, Florida. Bulletin of the American Association of Petroleum Geologists 50, 1927-1947.

Stearns, H.T., 1974. Submerged shorelines and shelves of the Hawaiian Islands and a revision of some of the eustatic emerged shorelines. Geological Society of America Bulletin 85, 795-804.

Stearns, H.T., 1978. Quaternary shorelines in the Hawaiian Islands. Bernice P. Bishop Museum Bulletin 237, 1-57.

Stearns, H.T., 1985. Geology of the State of Hawaii, 2nd Edition. Pacific Books, Palo Alto, California, 335 pp.

Stein, M., Wasserburg, G.J., Aharon, P., Chen, J.H., Zhu, Z.R., Bloom, A., Chappell, J., 1993. TIMS U-series dating and stable isotopes of the last interglacial event in Papua New Guinea. Geochimica et Cosmochimica Acta 57, 2541-2554.

Sterrer, W.E., 1986. Marine Fauna and Flora of Bermuda. WileyInterscience, New York, 742 pp.

Stirling, C.H., Esat, T.M., Lambeck, K., McCulloch, M.T., 1998. Timing and duration of the last interglacial; evidence for a restricted interval of widespread coral reef growth. Earth and Planetary Science Letters 160, 745-762.

Stirling, C.H., Esat, T.M., McCulloch, M.T., Lambeck, K., 1995. High-precision U-series dating of corals from Western Australia and implications for the timing and duration of the last interglacial. Earth and Planetary Science Letters 135, 115-130.

Szabo, B.J., 1979. ${ }^{230} \mathrm{Th},{ }^{231} \mathrm{~Pa}$, and open system dating of fossil corals and shells. Journal of Geophysical Research 84, 4927-4930.

Szabo, B.J., 1985. Uranium-series dating of fossil corals from marine sediments of southeastern United States Atlantic Coastal Plain. Geological Society of America Bulletin 96, 398-406.

Szabo, B.J., Gard, L.M., 1975. Age of the South Bight II marine transgression at Amchitka Island, Aleutians. Geology 3, 457-459.

Szabo, B.J., Moore, J.G., 1986. Age of $-360-\mathrm{m}$ reef terrace, Hawaii, and the rate of late Pleistocene subsidence of the island. Geology 14, 967-968.

Szabo, B.J., Ludwig, K.R., Muhs, D.R., Simmons, K.R., 1994. Thorium-230 ages of corals and duration of the last interglacial sea-level high stand on Oahu, Hawaii. Science 266, 93-96.

Toscano, M.A., Lundberg, J., 1999. Submerged late Pleistocene reefs on the tectonically stable S.E. Florida margin: high-precision geochronology, stratigraphy, resolution of substage 5a sea-level elevation, and orbital forcing. Quaternary Science Reviews 18, 753-767.

Tveranger, J., Houmark-Nielsen, M., Løvberg, K., Mangerud, J., 1994. Eemian-Weichselian stratigraphy of the Flakkerhuk ridge, southern Jameson Land, East Greenland. Boreas 23, 359-384.

Vacher, H.L., Hearty, P., 1989. History of stage 5 sea level in Bermuda: review with new evidence of a brief rise to present sea level during substage 5a. Quaternary Science Reviews 8, 159-168.

Vacher, H.L., Rowe, M.P., 1997. Geology and hydrogeology of Bermuda. In: Vacher, H.L., Quinn, T.M. (Eds.), Geology and
Hydrology of Carbonate Islands. Developments in Sedimentology 54. Elsevier, Amsterdam, pp. 35-90.

Vacher, H.L., Rowe, M., Garrett, P., 1989. The Geological Map of Bermuda, Scale 1: 25,000. Public Works Department, Hamilton, Bermuda.

Vacher, H.L., Hearty, P.J., Rowe, M.P., 1995. Stratigraphy of Bermuda: nomenclature, concepts, and status of multiple systems of classification. Geological Society of America Special Paper 300, 271-294.

Valentine, J.W., 1961. Paleoecologic molluscan geography of the Californian Pleistocene. University of California Publications in Geological Sciences 34, 309-442.

Veron, J.E.N., 1995. Corals in Space and Time: The Biogeography and Evolution of the Scleractinia. Comstock/Cornell, Ithaca, $321 \mathrm{pp}$.

Vézina, J., Jones, B., Ford, D., 1999. Sea-level highstands over the last 500,000 years: evidence from the Ironshore Formation on Grand Cayman, British West Indies. Journal of Sedimentary Research 69, $317-327$

Vollbrecht, R., 1990. Marine and meteoric diagenesis of submarine Pleistocene carbonates from the Bermuda carbonate platform. Carbonates and Evaporites 5, 13-96.

Warén, A., 1980. Revision of the genera Thyca, Stilifer, Scalenostoma, Mucronalia, and Euchineulima (Mollusca, Prosobranchia, Eulimidae). Zoological Scripta 9, 187-210.

Watts, A.B., ten Brink, U.S., 1989. Crustal structure, flexure, and subsidence history of the Hawaiian Islands. Journal of Geophysical Research 94, 10,473-10,500.

Wehmiller, J.F., Belknap, D.F., Boutin, B.S., Mirecki, J.E., Rahaim, S.D., York, L.L., 1988. A review of the aminostratigraphy of Quaternary mollusks from United States Atlantic Coastal Plain sites. Geological Society of America Special Paper 227, 69-110.

Wehmiller, J.F., Krantz, D.E., Simmons, K.R., Ludwig, K.R, Markewich, H.W., Rich, F., Hulbert Jr., R.C., 1997. US Atlantic Coastal Plain late Quaternary geochronology; TIMS U-series coral dates continue to indicate $80 \mathrm{kyr}$ sea level at or above present. Geological Society of America Abstracts with Programs $29(6), 346$.

Weisbord, N.E., 1974. Late Cenozoic corals of south Florida. Bulletins of American Paleontology 66, 258-544.

Winograd, I.J., Coplen, T.B., Landwehr, J.M., Riggs, A.C., Ludwig, K.R., Szabo, B.J., Kolesar, P.T., Revesz, K.M., 1992. Continuous 500,000 -year climate record from vein calcite in Devils Hole, Nevada. Science 258, 255-260.

Winograd, I.J., Landwehr, J.M., Ludwig, K.R., Coplen, T.B., Riggs, A.C., 1997. Duration and structure of the past four interglaciations. Quaternary Research 48, 141-154.

Wolfe, A.P., Fréchette, B., Richard, P.J.H., Miller, G.H., Forman, S.L., 2000. Paleoecology of a >90,000-year lacustrine sequence from Fog Lake, Baffin Island, Arctic Canada. Quaternary Science Reviews 19, 1677-1699.

Woodring, W.P., Bramlette, M.N., Kew, W.S.W., 1946. Geology and paleontology of Palos Verdes Hills, California. US Geological Survey Professional Paper 207, 145 pp.

Yamamoto, M., Yamamuro, M., Tada, R., 2000. Late Quaternary records of organic carbon, calcium carbonate, and biomarkers from Site 1016 off Point Conception, California margin. Proceedings of the Ocean Drilling Program, Scientific Results 167, 183-194. 